\title{
Myeloperoxidase-generated reactive nitrogen species convert LDL into an atherogenic form in vitro
}

\author{
Eugene A. Podrez, ${ }^{1}$ David Schmitt, ${ }^{1}$ Henry F. Hoff, ${ }^{1}$ and Stanley L. Hazen ${ }^{1,2,3}$ \\ ${ }^{1}$ Department of Cell Biology, and \\ ${ }^{2}$ Department of Cardiology, Cleveland Clinic Foundation, Cleveland, Ohio 44195, USA \\ ${ }^{3}$ Chemistry Department, Cleveland State University, Cleveland, Ohio, 44115, USA \\ Address correspondence to: Stanley L. Hazen, Cleveland Clinic Foundation, Lerner Research Institute, \\ Department of Cell Biology, 9500 Euclid Avenue, NC-10, Cleveland, Ohio 44195, USA. Phone: (216) 445-9763; \\ Fax: (216) 444-9404; E-mail: hazens@cesmtp.ccf.org
}

Received for publication October 19, 1998, and accepted in revised form April 22, 1999.

Oxidized LDL is implicated in atherosclerosis; however, the pathways that convert LDL into an atherogenic form in vivo are not established. Production of reactive nitrogen species may be one important pathway, since LDL recovered from human atherosclerotic aorta is enriched in nitrotyrosine. We now report that reactive nitrogen species generated by the $\mathrm{MPO}-\mathrm{H}_{2} \mathrm{O}_{2}-\mathrm{NO}_{2}{ }^{-}$system of monocytes convert LDL into a form $\left(\mathrm{NO}_{2}\right.$-LDL) that is avidly taken up and degraded by macrophages, leading to massive cholesterol deposition and foam cell formation, essential steps in lesion development. Incubation of LDL with isolated MPO, an $\mathrm{H}_{2} \mathrm{O}_{2}$-generating system, and nitrite $\left(\mathrm{NO}_{2}^{-}\right)$- a major end-product of NO metabolismresulted in nitration of apolipoprotein B 100 tyrosyl residues and initiation of LDL lipid peroxidation. The time course of LDL protein nitration and lipid peroxidation paralleled the acquisition of high-affinity, concentration-dependent, and saturable binding of $\mathrm{NO}_{2}$-LDL to human monocyte-derived macrophages and mouse peritoneal macrophages. LDL modification and conversion into a high-uptake form occurred in the absence of free metal ions, required $\mathrm{NO}_{2}^{-}$, occurred at physiological levels of $\mathrm{Cl}^{-}$, and was inhibited by heme poisons, catalase, and BHT. Macrophage binding of $\mathrm{NO}_{2}-\mathrm{LDL}$ was specific and mediated by neither the LDL receptor nor the scavenger receptor class A type I. Exposure of macrophages to $\mathrm{NO}_{2}$-LDL promoted cholesteryl ester synthesis, intracellular cholesterol and cholesteryl ester accumulation, and foam cell formation. Collectively, these results identify MPO-generated reactive nitrogen species as a physiologically plausible pathway for converting LDL into an atherogenic form.

J. Clin. Invest. 103:1547-1560 (1999).

\section{Introduction}

Oxidative modification of LDL is implicated in atherogenesis (1-5). A key early event is believed to be the conversion of LDL into a form capable of being recognized by "scavenger" or "oxidized LDL" receptors, whose surface expression is not diminished upon exposure to excess cholesterol (1-5). Direct demonstration of the oxidation pathways responsible for rendering LDL atherogenic in vivo, however, has proved difficult because of the evanescent nature of reactive oxidant species and the noninformative products they typically produce (6).

One potential pathway for LDL modification and conversion into a high-uptake form in vivo may involve reactive nitrogen species derived from nitric oxide (nitrogen monoxide, NO), a long-lived free radical that is formed by multiple vascular wall cells (7). NO is relatively unreactive toward most biomolecules and does not promote protein and lipid oxidation at neutral $\mathrm{pH}$. However, a variety of reactive nitrogen species derived from $\mathrm{NO}$ are capable of damaging biologic targets (8-14). Antibodies specific for nitrotyrosine, a marker for protein damage by reactive nitrogen species $(9,14,15)$, recognize epitopes in human atheroma but not in adjacent normal aortic intima (16). Mass spectrometric studies demonstrated nearly 100-fold-higher levels of nitrotyrosine in LDL recovered from human atherosclerotic aortae compared with LDL isolated from plasma of healthy donors (17).
Thus, multiple lines of evidence suggest that nitrating intermediates promote LDL oxidation in the human artery wall during atherosclerosis; however, the precise nitrating intermediates formed, the pathways responsible for their generation in vivo, and the biologic consequences of LDL nitration are still unknown.

The most well-studied pathway for generating nitrating intermediates from $\mathrm{NO}$ involves formation of peroxynitrite $\left(\mathrm{ONOO}^{-}\right)$, a product of $\mathrm{NO}$ and superoxide $\left(\mathrm{O}_{2}^{-}\right)(12)$. Bolus addition of reagent $\mathrm{ONOO}^{-}$to biologic targets promotes nitration of protein tyrosyl residues (14), depletes lipid-soluble antioxidants $(18,19)$, and initiates lipid peroxidation $(11,13)$. Multiple cellular components of human atherosclerotic lesions produce both $\mathrm{O}_{2}{ }^{-}$and $\mathrm{NO}$ (7), suggesting that $\mathrm{ONOO}^{-}$may contribute to LDL oxidation and nitrotyrosine formation in human atherosclerotic lesions. Recent studies have questioned the significance of $\mathrm{ONOO}^{-}$ in mediating protein nitration in vivo, however, because of the inefficient tyrosine nitration observed when this oxidizing agent is formed in situ at physiological $\mathrm{pH}$ and low equivalent fluxes of $\mathrm{NO}$ and $\mathrm{O}_{2}^{-}$(20). Moreover, enhanced NO production by macrophages has been shown to have a protective effect on the extent of cell-mediated oxidative damage of LDL (8).

Another potential pathway for generating reactive nitrogen species in vivo has recently been described that involves myeloperoxidase (MPO), an enzyme implicated 

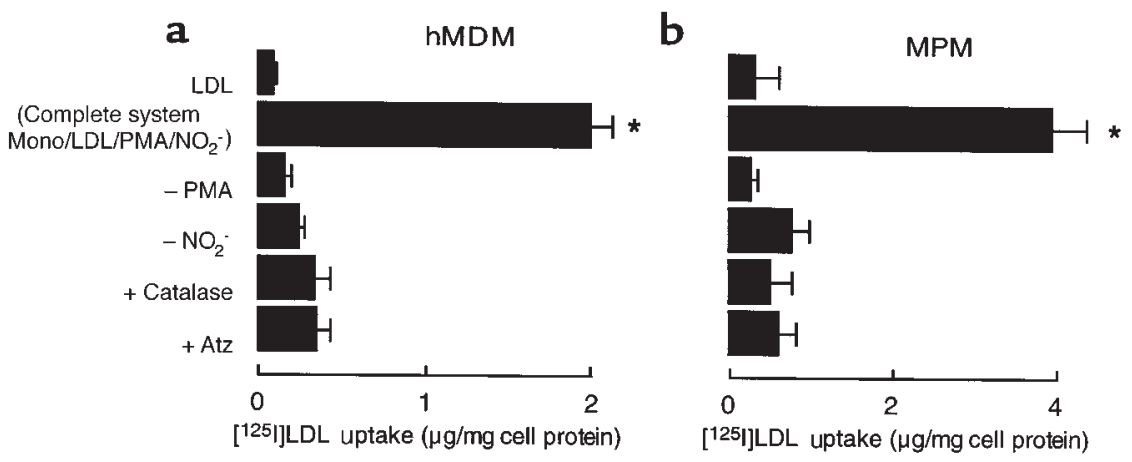

\section{Figure 1}

Degradation of [ ${ }^{125}$ ] LDL by hMDMs and MPMs after modification by activated human monocytes. Isolated human monocytes $\left(10^{6} / \mathrm{mL}\right)$ were incubated at $37^{\circ} \mathrm{C}$ in HBSS supplemented with DTPA $\left.\left.(100 \mu \mathrm{M}),{ }^{125}\right]\right] \mathrm{LDL}(0.2 \mathrm{mg} / \mathrm{mL})$, and $\mathrm{NO}_{2}{ }^{-}(500 \mu \mathrm{M})$. Monocytes were activated with phorbol ester $(200 \mathrm{nM})$ and maintained in suspensions by intermittent inversion (complete system) for 8 hours. Additions or deletions to the complete system were as indicated. Reactions were stopped by addition of BHT $(40 \mu \mathrm{M})$ and catalase $(300 \mathrm{nM})$; the cells were pelleted; and then ${ }^{125}$-labeled lipoproteins $(5 \mu \mathrm{g} / \mathrm{mL})$ were incubated with either hMDMs (a) or thioglycollate-elicited MPMs $(\mathbf{b})$ at $37^{\circ} \mathrm{C}$ for 5 hours in the appropriate media containing additional catalase $(300 \mathrm{nM})$ and $\mathrm{BHT}(20 \mu \mathrm{M})$. Cellular uptake of lipoproteins was subsequently determined as described in Methods. The final concentrations of additions to the complete system were catalase $(300 \mathrm{nM})$ and 3 -aminotriazole $(1 \mathrm{mM})$. Data represent the mean \pm SD of 3 separate experiments. ${ }^{*} P<0.001$ for complete system vs. complete system $-\mathrm{NO}_{2}{ }^{-}$. Atz, 3-aminotriazole; Mono, human peripheral blood monocyte.

in atherosclerosis. MPO is an abundant heme protein that is secreted from activated phagocytes (21). It amplifies the oxidizing potential of $\mathrm{H}_{2} \mathrm{O}_{2}$ by using it as cosubstrate to generate a variety of cytotoxic oxidants (22-27). Antibodies specific for MPO demonstrate that the enzyme is localized in human atherosclerotic lesions (28). One major and unique oxidant formed by MPO in vivo is hypochlorous acid ( $\mathrm{HOCl})$, a potent chlorinating agent generated by the oxidation of chloride $(23,29,30)$. Both mass spectrometric and immunohistochemical studies demonstrate that $\mathrm{HOCl}$-generated protein oxidation products are enriched in human atherosclerotic aortic intima and LDL recovered from human atherosclerotic lesions $(29,31)$. Thus, MPO-generated oxidants are formed in diseased human vascular tissues.

Several recent studies demonstrate that MPO also utilizes $\mathrm{H}_{2} \mathrm{O}_{2}$ and nitrite $\left(\mathrm{NO}_{2}^{-}\right)$, the autoxidation product of $\mathrm{NO}$, as cosubstrates to generate a microbicidal oxidant (32) capable of nitrating phenolic compounds and proteins in vitro $(25,26,33,34) . \mathrm{NO}_{2}^{-}$is ubiquitous in biologic tissues and fluids (25). Plasma and extracellular levels of $\mathrm{NO}_{2}^{-}$are markedly increased in inflammatory and infectious processes in which NO production is enhanced (35-37). Studies with isolated MPO and human neutrophils demonstrate that the enzyme catalyzes aromatic nitration in media containing concentrations of $\mathrm{NO}_{2}^{-}$approximating those found in biologic fluids, confirming that this major NO metabolite can serve as a physiological substrate for MPO in the presence of plasma levels of chloride $(26,38)$.

Here, we explore the role of MPO-generated reactive nitrogen species in converting LDL into a novel proatherogenic form. We now report that exposure of $\mathrm{LDL}$ to the MPO- $\mathrm{H}_{2} \mathrm{O}_{2}-\mathrm{NO}_{2}^{-}$system of phagocytes results in concomitant apo B-100 protein nitration, induction of LDL lipid peroxidation, and conversion of the lipoprotein into a form capable of promoting macrophage cholesteryl ester accumulation and foam cell formation, essential steps in the atherosclerotic process.

\section{Methods}

Materials. L- $\left[{ }^{13} \mathrm{C}_{6}\right]$ tyrosine was purchased from Cambridge Isotopes Inc. (Andover, Massachusetts, USA). Tissue culture media and additives were purchased from Life Technologies Inc. (Gaithersburg, Maryland, USA). [ $\left.{ }^{125} \mathrm{I}\right] \mathrm{NaI}$ and $\left[{ }^{14} \mathrm{C}\right]$ oleate were supplied by ICN Pharmaceuticals Inc. (Costa Mesa, California, USA). C57BL/ 6 mice (16-20 weeks of age) were purchased from the Trudeau Institute (Saranac Lake, New York, USA). THP-1 cells were obtained from American Type Culture Collection (Rockville, Maryland, USA). All other reagents were obtained from Sigma Chemical Co. (St. Louis, Missouri, USA) unless otherwise specified.

General procedures. All buffers were passed over a column of Chelex-100 resin (Bio-Rad Laboratories Inc., Hercules, California, USA) and supplemented with diethylenetriamine pentaacetic acid (DTPA) to remove any potential transition metal ions that might catalyze LDL oxidation during incubations. Peroxynitrite was synthesized and quantified as described (14). L-3- $\left[{ }^{13} \mathrm{C}_{6}\right]$ nitrotyrosine was made from $\mathrm{L}-\left[{ }^{13} \mathrm{C}_{6}\right]$ tyrosine and peroxynitrite and was isolated by reverse-phase HPLC to remove residual $\mathrm{NO}_{2}{ }^{-}$before use (17). Protein content was determined by the Markwell-modified Lowry protein assay (39), with BSA as standard. Production of $\mathrm{H}_{2} \mathrm{O}_{2}$ by glucose/glucose oxidase (GGOx) was quantified by oxidation of $\mathrm{Fe}(\mathrm{II})$ and formation of an $\mathrm{Fe}(\mathrm{III})$-thiocyanate complex (25). The concentration of reagent $\mathrm{H}_{2} \mathrm{O}_{2}$ was determined spectrophotometrically $\left(\varepsilon_{240}=39.4 \mathrm{M}^{-1} / \mathrm{cm}^{-1}\right.$; ref. 40$)$. LDL was acetylated with acetic acid anhydride (41). Acetylated lipoproteins were dialyzed against $0.15 \mathrm{M} \mathrm{NaCl}, 0.3 \mathrm{mM} \mathrm{Na}_{2}$ EDTA, and $100 \mu \mathrm{M}$ DTPA (pH 7.4). LDL labeling with [125I]NaI and agarose gel electrophoresis were performed as described previously (42). The specific activity of labeled LDL preparations was between 100 and $250 \mathrm{dpm} / \mathrm{ng}$ protein. Cholesterol and cholesteryl ester content, and cholesteryl $\left[{ }^{14} \mathrm{C}\right]$ oleate synthesis by cells incubated with the indicated lipoproteins $(50$ $\mu \mathrm{g} / \mathrm{mL}$ ), were determined by published methods (41). $\alpha$-tocopherol levels were determined as described (43). LDL concentrations are expressed as milligrams of protein per milliliter. MPO and lipoprotein isolation. MPO (donor: hydrogen peroxide, oxidoreductase, EC 1.11.1.7) was initially purified from detergent extracts of human leukocytes by sequential lectin affinity and gel filtration chromatography as described by Rakita et al. (44). Trace levels of contaminating eosinophil peroxidase were 
then removed by passage over a sulfopropyl Sephadex column (45). Purity of isolated MPO was established by demonstrating an $R Z$ of $0.87\left(\mathrm{~A}_{430} / \mathrm{A}_{280}\right)$, SDS-PAGE analysis with Coomassie blue staining, and in-gel tetramethylbenzidine peroxidase staining (46). Enzyme concentration was determined spectrophotometrically utilizing an extinction coefficient of $89,000 \mathrm{M}^{-1} /$ $\mathrm{cm}^{-1} /$ heme of MPO (22). The concentration of the MPO dimer was calculated as half the indicated concentration of heme-like chromophore. LDL was isolated from fresh plasma by sequential ultracentrifugation as a $1.019<d<1.063 \mathrm{~g} / \mathrm{mL}$ fraction (47). Final preparations were placed in $50 \mathrm{mM}$ sodium phosphate ( $\mathrm{pH} 7.0$ ), $200 \mu \mathrm{M}$ DTPA (by passage over 10-DG desalting columns; Bio-Rad Laboratories Inc.) and stored under $\mathrm{N}_{2}$ until use.

Lipoprotein oxidation. $\mathrm{NO}_{2}$-LDL was prepared by incubating LDL $\left(0.2 \mathrm{mg}\right.$ protein $/ \mathrm{mL}$ ) at $37^{\circ} \mathrm{C}$ in $50 \mathrm{mM}$ sodium phosphate ( $\mathrm{pH} 7.0$ ), $100 \mu \mathrm{M}$ DTPA in the presence of $30 \mathrm{nM}$ MPO, $100 \mu \mathrm{g} / \mathrm{mL}$ glucose, $20 \mathrm{ng} / \mathrm{mL}$ glucose oxidase (grade II; Boehringer Mannheim Biochemicals, Indianapolis, Indiana, USA), and $0.5 \mathrm{mM} \mathrm{NaNO}_{2}$ for 8 hours unless otherwise specified. Preliminary studies demonstrated that under these conditions, a constant flux of $\mathrm{H}_{2} \mathrm{O}_{2}(0.18 \mu \mathrm{M} / \mathrm{min})$ is generated by the GGOx system. Unless otherwise stated, oxidation reactions were terminated by addition of $40 \mu \mathrm{M}$ butylated hydroxytoluene (BHT; from a $100 \mathrm{mM}$ ethanolic stock) and $300 \mathrm{nM}$ catalase to the reaction mixture. Preliminary studies demonstrated that monocytes isolated by methods that use adhesion/washing steps contained less MPO per cell (presumably because of some premature degranulation during the isolation procedure). Human peripheral blood monocytes used for LDL oxidation were therefore isolated by elutriation (48). Monocytes $\left(1 \times 10^{6} / \mathrm{mL}\right)$ were incubated with $\mathrm{LDL}(0.2 \mathrm{mg} / \mathrm{mL})$ in HBSS (magnesium-, calcium-, phenol-, and bicarbonate-free; $\mathrm{pH} 7.20)$ supplemented with DTPA $(100 \mu \mathrm{M})$ for 8 hours at $37^{\circ} \mathrm{C}$ in the presence of the additions or deletions indicated. Reactions were terminated by addition of BHT $(20 \mu \mathrm{M})$ and pelleting of cells. Oxidation of LDL $(0.2 \mathrm{mg} / \mathrm{mL})$ by copper was performed by dialysis vs. $5 \mu \mathrm{M} \mathrm{CuSO}_{4}$ in PBS for 24 hours. Oxidation was terminated by addition of BHT $(40 \mu \mathrm{M})$ and dialysis against PBS containing DTPA $(100 \mu \mathrm{M})$. Aggregated LDL for cytochalasin D experiments was produced by vortexing solutions of LDL $(500 \mu \mathrm{g} / \mathrm{mL}$ in $0.15 \mathrm{M} \mathrm{NaCl}, 0.3 \mathrm{mM}$ $\mathrm{Na}_{2}$ EDTA, $40 \mu \mathrm{M}$ BHT).
Analysis of lipid peroxidation products. Lipids were extracted by a modified Dole procedure as described by Savenkova et al. (49). Lipids were dried under nitrogen and resuspended in $1 \%$ sodium dodecylsulfate, and total lipid hydroperoxides were then measured as described (50). Total (free and esterified) 9hydroxy-10,12-octadecadienoic acid + 9-hydroperoxy-10,12octadecadienoic acid [9-H(P)ODE] formed was determined by reverse-phase HPLC of triphenylphosphine-reduced lipid extracts after base hydrolysis as described previously (49). Authentic (E,Z)-9-hydroxy-10,12-octadecadienoic acid (9HODE; Cayman Chemical Co., Ann Arbor, Michigan, USA) was used as standard. Cholesteryl-9-hydroxy-10,12-octadecadienoate + cholesteryl-9-hydroperoxy-10,12-octadecadienoate [9-H(P)ODE] was quantified by reverse-phase HPLC of triphenylphosphine-reduced lipid extracts (not subjected to base hydrolysis) as described (49). (E,Z)-cholest-5-en-ol(3 $\beta)$-9hydroxy-10,12-octadecadienoate (cholesteryl-9-HODE; Cayman Chemical Co.) was used as standard. The content of thiobarbituric acid (TBA) reactive products in LDL preparations was determined by fluorescence analysis (51) in the presence of $0.05 \%$ (wt/vol) BHT. Fluorescence measurements (2-nm slit width, excitation $515 \mathrm{~nm}$, emission $553 \mathrm{~nm}$ ) were made on an LS-3 Fluorescence Spectrometer (Perkin-Elmer Corp., Norwalk, Connecticut, USA) using an external calibration curve constructed with known amounts of malondialdehyde (MDA) obtained from hydrolysis of 1,1,3,3-tetramethoxypropane in $20 \%$ acetic acid ( $\mathrm{pH} 3.5$ ). Total lipid hydroperoxides, total 9$\mathrm{H}(\mathrm{P}) \mathrm{ODE}$, cholesteryl-9-H(P)ODE, and TBA reactive products are expressed as nanomole of oxidation product per milligram of LDL protein.

Analysis of LDL protein oxidation products and amino acids. Nitrotyrosine content was determined by stable isotope dilution gas chromatography-mass spectrometry (GC/MS) on a Turbomass Spectrometer (Perkin-Elmer Corp.) equipped with chemical ionization probe. Briefly, reactions were terminated by addition of BHT and catalase as already described here; lipids and salts were removed by extraction with a single-phase solvent mixture of $\mathrm{H}_{2} \mathrm{O}$ /water-washed diethyl ether/methanol $(1: 3: 7, \mathrm{vol} / \mathrm{vol} / \mathrm{vol})(52)$; and the nitrotyrosine content in amino acid hydrolysates was determined after reduction to amino tyrosine as an $n$-propyl, per heptafluorobutyryl derivative (53). Nitrotyrosine content is normalized to the content of tyrosine determined by stable isotope dilution GC/MS (24).
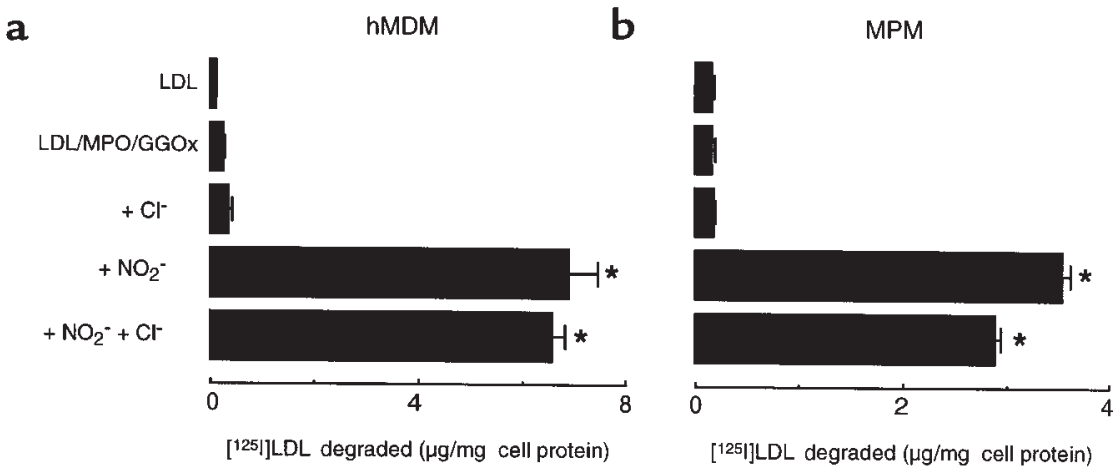

Figure 2

Degradation of [ ${ }^{125}$ ] LDL by hMDMs and MPMs after modification by MPO-generated chlorinating and nitrating intermediates. [125I]LDL (0.2 $\mathrm{mg} / \mathrm{mL})$ was incubated with isolated human MPO $(30 \mathrm{nM})$, glucose $(100 \mu \mathrm{M})$, and glucose oxidase $(20 \mathrm{ng} / \mathrm{mL})$ in the presence of the indicated additions in sodium phosphate buffer $(50 \mathrm{mM}, \mathrm{pH} 7.0)$ supplemented with DTPA $(100 \mu \mathrm{M})$ overnight at $37^{\circ} \mathrm{C}$, as described in Methods. Under these conditions, a constant flux of $\mathrm{H}_{2} \mathrm{O}_{2}(0.18 \mu \mathrm{M} / \mathrm{min}$ ) is generated by the GGOx system. Reactions were stopped by addition of $\mathrm{BHT}(40 \mu \mathrm{M})$ and catalase $(300 \mathrm{nM})$, and then ${ }^{125}$-labeled lipoproteins $(5 \mu \mathrm{g} / \mathrm{mL})$ were incubated with either hMDMs (a) or thioglycollate-elicited $\mathrm{MPMs}(\mathbf{b})$ at $37^{\circ} \mathrm{C}$ for 5 hours in the appropriate media containing additional catalase $(300 \mathrm{nM})$ and BHT $(20 \mu \mathrm{M})$. Cellular uptake of lipoproteins was subsequently determined as described in Methods. When indicated, $\mathrm{Cl}^{-}(100 \mathrm{mM})$ or $\mathrm{NO}_{2}{ }^{-}(500 \mu \mathrm{M})$ were added during LDL modification by MPO. Data represent the mean \pm SD of triplicate determinations. Similar results were observed in 3 independent experiments. ${ }^{*} P<0.001$ for comparison vs. LDL modified in the presence of MPO and an $\mathrm{H}_{2} \mathrm{O}_{2}$-generating system (LDL/MPO/GGOx). 
a

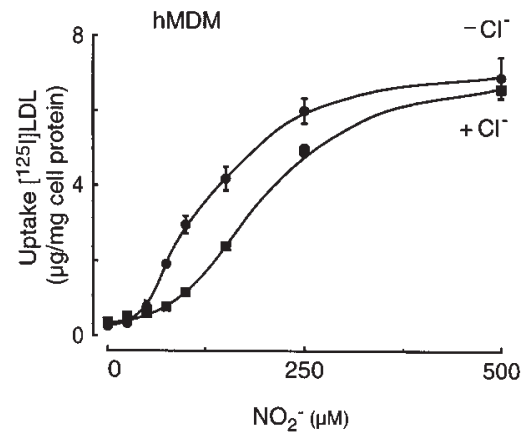

b

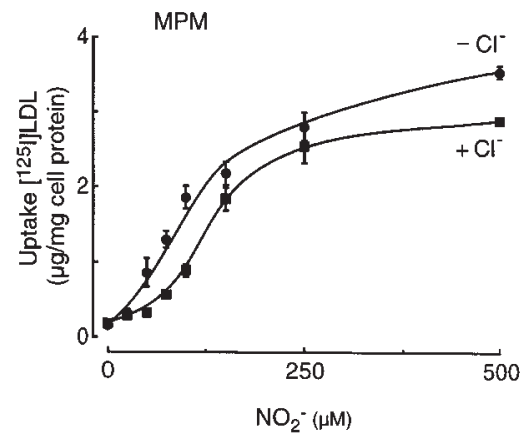

\section{Figure 3}

$\mathrm{NO}_{2}{ }^{-}$concentration dependence of MPO-mediated modification of LDL and conversion into a high-uptake form for macrophages. [ ${ }^{125}$ I] LDL $(0.2$ $\mathrm{mg} / \mathrm{mL}$ ) was incubated with isolated human MPO (30 nM), glucose (100 $\mu \mathrm{M})$, glucose oxidase $(20 \mathrm{ng} / \mathrm{mL})$, and the indicated concentrations of $\mathrm{NO}_{2}^{-}$, in the absence (filled circles) and presence (filled squares) of $\mathrm{Cl}^{-}$ (100 mM) in sodium phosphate buffer (50 mM, pH 7.0) supplemented with DTPA $(100 \mu \mathrm{M})$ overnight at $37^{\circ} \mathrm{C}$, as described in Methods. Uptake of the modified lipoproteins was then assessed using hMDMs (a) and thioglycollate-elicited MPMs (b) as described in Methods. Data represent the mean $\pm S D$ of triplicate determinations. Similar results were observed in 3 independent experiments.

Samples from time-course experiments quantifying remaining lysine and tryptophan residues were quenched with addition of $200 \mu \mathrm{M}$ BHT and immediately analyzed. Unmodified lysine residues in LDL were quantified by fluorescamine fluorescence (54). $N^{\alpha}$-acetyl lysine was used as standard to construct an external calibration curve. The fluorescence of treated samples was expressed relative to that of native LDL, assuming that the lipoprotein contains 341 lysine residues per particle, the number of lysines present in mature apo B-100 (55). Tryptophan fluorescence of LDL was measured using excitation and emission wavelengths of $280 \mathrm{~nm}$ and $335 \mathrm{~nm}$, respectively (54). A linear relationship between loss of fluorescence and number of tryptophan residues oxidized was assumed. Results are expressed relative to those of native LDL; it was assumed that apo B-100 of native LDL contains 37 tryptophan residues (55).

Cells. Elicited mouse peritoneal macrophages (MPMs) were harvested by peritoneal lavage with ice-cold PBS 2-3 days after thioglycollate stimulation of female C57BL/6 mice (42). Resident MPMs were similarly harvested from mice not subjected to thioglycollate stimulation. Primary cultures were prepared at a density of $10^{6}$ cells per 16-mm-diameter well in RPMI- 1640 containing $10 \% \mathrm{FBS}$ and were used 48 hours after plating. Chinese hamster ovary $(\mathrm{CHO})$ cells expressing mouse scavenger receptor class A type I (CHO-mSR-AI) and control vector-transfected parental CHO cells were a generous gift of M. Krieger (Massachusetts Institute of Technology, Boston, Massachusetts, USA) and were cultured as described elsewhere (56). Experiments were performed on confluent cell monolayers in Ham's F-12 medium containing 3\% lipoprotein-deficient FCS, BHT $(20 \mu \mathrm{M})$, DTPA $(100 \mu \mathrm{M})$, and catalase (300 nM). THP-1 cells were plated at a density of $0.5 \times 10^{6}$ cells per well and incubated with 64 nM PMA in RPMI-1640 with $10 \%$ FBS and $50 \mu \mathrm{M} \beta$-mercaptoethanol for 3 days before use. hMDMs were prepared from isolated human peripheral blood monocytes cultured 10-14 days in macrophage serum-free media (Gibco BRL, Grand Island, New York, USA) supplemented with GM-CSF (20 ng/mL) (48). Experiments with hMDMs were performed on confluent cell monolayers in the same medium containing $200 \mu \mathrm{g} / \mathrm{mL} \mathrm{LDL}$ (to block LDL receptor-mediated recognition of LDL preparations), BHT $(20 \mu \mathrm{M})$, DTPA $(100 \mu \mathrm{M})$, and catalase (300 $\mathrm{nM})$.

Lipoprotein uptake, degradation, and binding by cultured cells. BHT $(20 \mu \mathrm{M})$, catalase $(300 \mathrm{nM})$, and DTPA $(100 \mu \mathrm{M})$ were included in the media of all uptake, degradation, and binding experiments to inhibit lipoprotein oxidation during incubation with cells. Cells were washed with serum-free medium, and the indicated amounts of ${ }^{125}$ I-labeled native or modified LDL were added in $250 \mu \mathrm{L}$ of the appropriate media. After a 5-hour incubation at $37^{\circ} \mathrm{C}$, lipoprotein degradation was assessed by removal of media and quantifying TCA-soluble, noniodide degradation products $(41,42)$. Cells were also washed and assayed for cell-associated label and protein content $(41,42)$. Cell-free control experiments were performed in parallel and subtracted from counts in cellcontaining reactions to calculate cell-dependent lipoprotein degradation (cell-free controls were $<10 \%$ of the observed TCAsoluble counts in cell-containing reactions). Total uptake was calculated from the sum of degradation and cell-associated label. In competition experiments, ${ }^{125}$ I-labeled lipoprotein $(5 \mu \mathrm{g} / \mathrm{mL})$ was incubated with cells in the presence of $200 \mu \mathrm{g} / \mathrm{mL}$ of unlabeled competitor. Lipoprotein binding to macrophages at $4^{\circ} \mathrm{C}$ was determined after 4-hour incubations of the indicated amounts of modified forms of [125I]LDL, as described (41).

Size exclusion chromatography. [125I]LDL $(2 \mathrm{mg}$ in $0.5 \mathrm{~mL}$ of 50 $\mathrm{mM}$ sodium phosphate buffer [ $\mathrm{pH} 7.0$ ] containing $200 \mu \mathrm{M}$ DTPA, $5 \mathrm{mg} / \mathrm{mL}$ BSA) was applied to a Sephacryl S400-HR column $(1.0 \times 45 \mathrm{~cm})$ pre-equilibrated in $50 \mathrm{mM}$ sodium phosphate buffer ( $\mathrm{pH} 7.0$ ) containing $200 \mu \mathrm{M}$ DTPA. Lipoproteins were eluted at a flow rate $10 \mathrm{~mL} / \mathrm{h}$, and radioactivity in $1.1-\mathrm{mL}$ fractions was determined.

Statistics. Data represent the mean \pm SD of the indicated number of samples. Statistical analyses were made using a paired Student's $t$ test. For all hypotheses, the significance level was 0.05 . When multiple comparisons were made, a Bonferroni correction to the significance criterion for each test was made.

\section{Results}

Human monocytes use the MPO- $\mathrm{H}_{2} \mathrm{O}_{2}-\mathrm{NO}_{2}^{-}$system to convert $L D L$ into a bigh-uptake form. We hypothesized that phagocytes might use the MPO- $\mathrm{H}_{2} \mathrm{O}_{2}-\mathrm{NO}_{2}^{-}$system to generate a nitrating intermediate that can oxidatively modify LDL, rendering it a ligand for macrophage recognition. To test this hypothesis, we incubated LDL with activated human monocytes in the absence and presence of $\mathrm{NO}_{2}^{-}$and then determined whether the lipoprotein was converted into a high-uptake form for macrophages. LDL modified by activated human monocytes in the absence of $\mathrm{NO}_{2}^{-}$ demonstrated only a modest increase in the extent of LDL uptake by macrophages (Figure 1). In contrast, human monocytes activated in the presence of $\mathrm{NO}_{2}{ }^{-}$converted the lipoprotein into a form that was readily taken up and degraded by both hMDMs (Figure 1a) and thioglycollate-elicited MPMs (Figure 1b). Conversion of LDL into a high-uptake form by monocytes required cell activation and was inhibited by either the $\mathrm{H}_{2} \mathrm{O}_{2}$ scavenger 


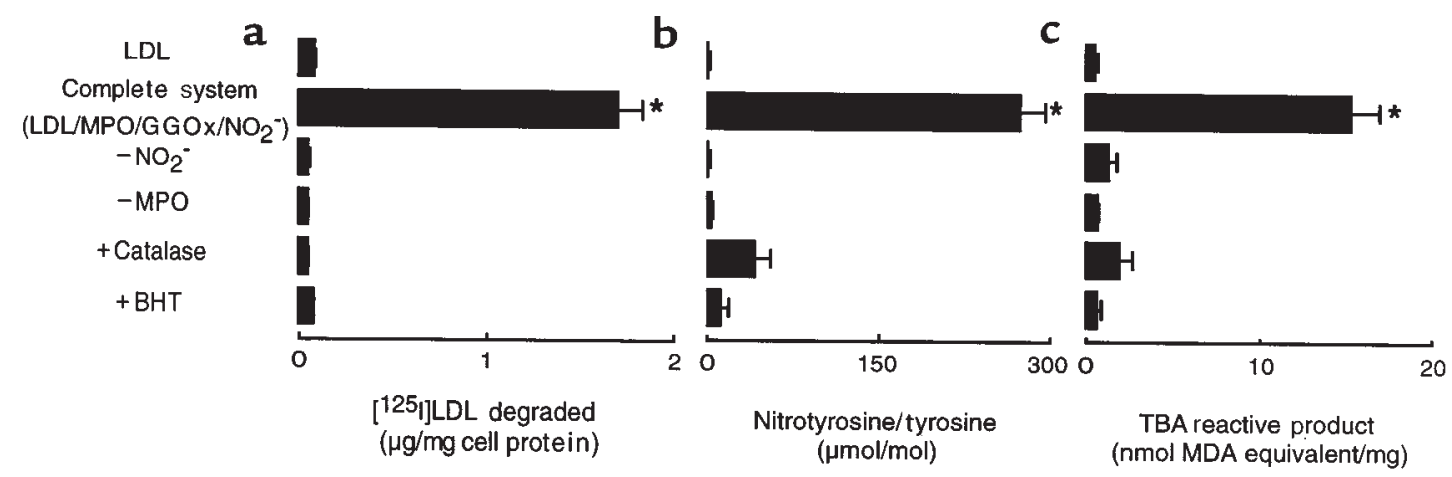

Figure 4

$\mathrm{LDL}$ protein nitration, lipid peroxidation, and conversion into a high-uptake form for macrophages mediated by the $\mathrm{MPO}-\mathrm{H}_{2} \mathrm{O}_{2}-\mathrm{NO}_{2}{ }^{-}$system. [ ${ }^{125}$ I] $\mathrm{LDL}$ $(0.2 \mathrm{mg} / \mathrm{mL})$ was incubated with isolated human MPO $(30 \mathrm{nM})$, glucose $(100 \mu \mathrm{M})$, glucose oxidase $(20 \mathrm{ng} / \mathrm{mL})$, and $\mathrm{NO}_{2}{ }^{-}(500 \mu \mathrm{M})$ in sodium phosphate buffer $(50 \mathrm{mM}, \mathrm{pH} 7.0)$ supplemented with DTPA $(100 \mu \mathrm{M})($ complete system) or the indicated additions or deletions. The degradation of lipoproteins by thioglycollate-elicited MPMs (a), the content of nitrotyrosine (b), and TBA reactive products (c) generated were then determined as described in Methods. Data represent the mean \pm SD for 3 independent experiments. ${ }^{*} P<0.001$ for complete system vs. complete system $-\mathrm{NO}_{2}-$.

catalase or peroxidase inhibitors, e.g., 3-aminotriazole). These results suggest that monocytes may use the MPO$\mathrm{H}_{2} \mathrm{O}_{2}-\mathrm{NO}_{2}^{-}$system for oxidative conversion of LDL into an atherogenic form. They also suggest that the MPO$\mathrm{H}_{2} \mathrm{O}_{2}$ system of monocytes may use $\mathrm{NO}_{2}^{-}$as substrate even in the presence of plasma levels of $\mathrm{Cl}^{-}$. Finally, macrophage recognition of monocyte-modified LDL appears to involve a mechanism(s) distinct from the LDL receptor, as excess native LDL that was included in the media during exposure of hMDMs to monocyte-modified $\left.{ }^{125} \mathrm{I}\right] \mathrm{LDL}$ preparations (see Methods) did not inhibit's uptake of monocyte-modified LDL.

LDL oxidized by $\mathrm{MPO}, \mathrm{H}_{2} \mathrm{O}_{2}$, and physiological levels of $\mathrm{NO}_{2}$ is converted into a form $\left(\mathrm{NO}_{2}-\mathrm{LDL}\right)$ that is avidly taken up and degraded by macrophages. Activated monocytes can generate a host of reactive oxidant species, which could have contributed to LDL modification and conversion into a high-uptake form. For example, direct exposure of LDL to additions of either $\operatorname{HOCl}(54,57)$ or $\mathrm{HOCl}$ in the presence of $\mathrm{NO}_{2}{ }^{-}(58)$ has been reported to result in lipoprotein aggregation and conversion into a high-uptake form for macrophages. Thus, a role for $\mathrm{HOCl}$ production by the MPO- $\mathrm{H}_{2} \mathrm{O}_{2}$ system of the cells could not be excluded as a contributor to the cell-dependent conversion of LDL into a form with enhanced macrophage recognition. To explore more fully the mechanism(s) through which the MPO- $\mathrm{H}_{2} \mathrm{O}_{2}$ system of monocytes might render LDL atherogenic, we used model systems to evaluate the ability of MPO-generated chlorinating and nitrating intermediates to convert LDL into a form that is recognized by macrophages. [ $\left.{ }^{125} \mathrm{I}\right] \mathrm{LDL}$ was incubated with MPO isolated from human leukocytes, an $\mathrm{H}_{2} \mathrm{O}_{2}$-generating system (GGOx) that produced a low flux of peroxide similar to that which might occur in vivo, and substrate (either $\mathrm{Cl}^{-}$or $\mathrm{NO}_{2}^{-}$, or both). The ability of the modified lipoprotein to be taken up and degraded by either hMDMs or thioglycollate-elicited MPMs was then determined. Incubation of LDL in the presence of an HOCl-generating system (MPO, GGOx, and $\mathrm{Cl}^{-}$) failed to convert the lipoprotein into a stable high-uptake form (Figure 2). In contrast, exposure of LDL to MPO and the $\mathrm{H}_{2} \mathrm{O}_{2}$-generating system, but with $\mathrm{NO}_{2}{ }^{-}$added, transformed the particle into a form readily taken up and degraded by macrophages (Figure 2). Moreover, addition of plasma
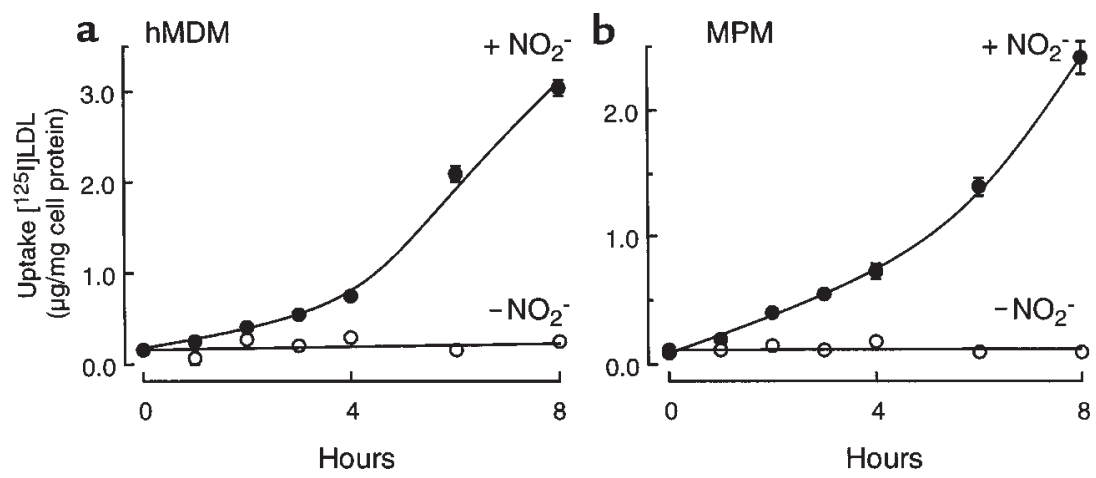

Figure 5

Time course of $\mathrm{LDL}$ conversion into a high-uptake form after exposure to the MPO- $\mathrm{H}_{2} \mathrm{O}_{2}-\mathrm{NO}_{2}{ }^{-}$system. [125/]LDL $(0.2 \mathrm{mg} / \mathrm{mL})$ was incubated with isolated human MPO $(30 \mathrm{nM})$, glucose $(100 \mu \mathrm{M})$, and glucose oxidase $(20 \mathrm{ng} / \mathrm{mL})$ in sodium phosphate buffer $(50 \mathrm{mM}, \mathrm{pH} 7.0)$ supplemented with DTPA $(100 \mu \mathrm{M})$ for the indicated times in either the presence $\left(+\mathrm{NO}_{2}^{-}\right.$; filled circles) or absence $\left(-\mathrm{NO}_{2}^{-}\right.$; open circles) of $\mathrm{NO}_{2}^{-}(500 \mu \mathrm{M})$ as described in Methods. Uptake of the modified lipoprotein by hMDMs (a) and thioglycollate-elicited MPMs (b) was then determined as described in Methods. Data represent the mean \pm SD for triplicate determinations. Similar results were observed in 3 independent experiments. 
a

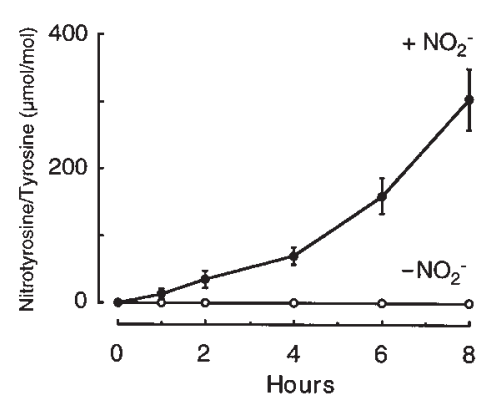

b



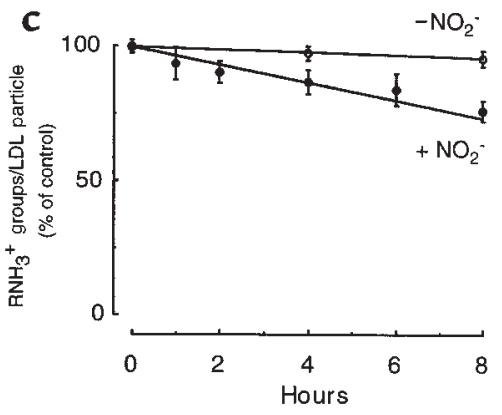

d

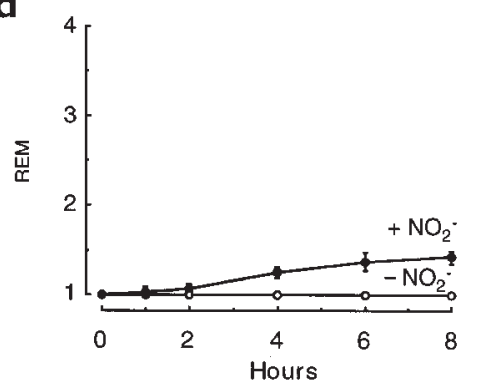

Figure 6

Characterization of multiple protein components of LDL exposed to the MPO- $\mathrm{H}_{2} \mathrm{O}_{2}-\mathrm{NO}_{2}^{-}$system. LDL samples prepared for Figure 5 were analyzed for nitrotyrosine content (a) tryptophan fluorescence (b), unmodified $\mathrm{N}^{\varepsilon}$-lysine groups (c), and lipoprotein REM (d), as described in Methods. Under the conditions used, the REM for exhaustively acetylated LDL is 3.8. Data represent the mean \pm SD of 3 independent experiments (1 using ${ }^{125}$-labeled LDL as starting material, and 2 using nonlabeled LDL as starting material). $+\mathrm{NO}_{2}^{-}$(filled circles), LDL modified by MPO, an $\mathrm{H}_{2} \mathrm{O}_{2}$-generating system (GGOx), and $\mathrm{NO}_{2}{ }^{-}$as described in Figure 5; - $\mathrm{NO}_{2}^{-}$(open circles), LDL modified by MPO and an $\mathrm{H}_{2} \mathrm{O}_{2}$-generating system (GGOx) as described in Figure 5.

levels of $\mathrm{Cl}^{-}$to $\mathrm{NO}_{2}^{-}$-containing reaction mixtures only modestly inhibited conversion of LDL into a high-uptake form. These results suggest that under conditions in which MPO-generated oxidants are formed by a physiological flux of $\mathrm{H}_{2} \mathrm{O}_{2}$, the reactive nitrogen species formed by the MPO- $\mathrm{H}_{2} \mathrm{O}_{2}-\mathrm{NO}_{2}{ }^{-}$system (presumably $\mathrm{NO}_{2}$; ref. 25 ) is more effective than either $\mathrm{HOCl}$ (product of the $\mathrm{MPO}-\mathrm{H}_{2} \mathrm{O}_{2}-\mathrm{Cl}^{-}$system) or $\mathrm{NO}_{2} \mathrm{Cl}$ (the presumed nitrating intermediate formed by the reaction of $\mathrm{NO}_{2}{ }^{-}$and $\mathrm{HOCl}$; ref. 33) in converting LDL into a stable highuptake form for macrophages.

The concentration of $\mathrm{NO}_{2}^{-}$in aortic intima is unknown. Plasma levels of $\mathrm{NO}_{2}^{-}$are normally $1-5 \mu \mathrm{M}$ but can increase more than 10 -fold during inflammation. Because the major pathway for $\mathrm{NO}_{2}^{-}$removal is through reaction with oxyhemoglobin-forming nitrate $\left(\mathrm{NO}_{3}^{-}\right)$, levels of $\mathrm{NO}_{2}^{-}$in inflamed extracellular fluids and tissues are likely higher $(25,35-37)$. We therefore evaluated the $\mathrm{NO}_{2}^{-}$concentration dependence of LDL modification and conversion into a high-uptake form by MPO in the absence and presence of plasma levels (100 $\mathrm{mM}$ ) of $\mathrm{Cl}^{-}$. Incubation of LDL with $\mathrm{MPO}$ and an $\mathrm{H}_{2} \mathrm{O}_{2-}$ generating system in the presence of increasing concentrations of $\mathrm{NO}_{2}{ }^{-}$resulted in progressively enhanced association, uptake, and degradation of the modified lipoprotein by all macrophages examined, i.e., both resident and elicited MPMs, THP- 1 cells (a human acute monocytic leukemia cell line), and hMDMs. Data for lipoprotein uptake after modification by the MPO$\mathrm{H}_{2} \mathrm{O}_{2}-\mathrm{NO}_{2}^{-}$system in the absence and presence of $\mathrm{Cl}^{-}$by hMDMs (Figure 3a) and thioglycollate-elicited MPMs (Figure $3 \mathrm{~b}$ ) are shown. The presence of plasma levels of $\mathrm{Cl}^{-}(100 \mathrm{mM})$ during MPO-dependent modification of the lipoprotein only modestly inhibited the ability of the peroxidase to utilize $\mathrm{NO}_{2}{ }^{-}$as substrate and convert the lipoprotein into a high-uptake form. Half maximal uptake by macrophages was observed at $\sim 100 \mu \mathrm{M} \mathrm{NO}_{2}$ for both hMDMs and MPMs (Figure 3), and significant increases in cell recognition were noticeable even when LDL was modified by MPO in the presence of $25 \mu \mathrm{M}$ $\mathrm{NO}_{2}{ }^{-}$, the lowest concentration examined $(P<0.05$ when comparing LDL modified with 0 vs. $25 \mu \mathrm{M} \mathrm{NO}_{2}{ }^{-}$in both the absence and presence of $\mathrm{Cl}^{-}$for both cell types). Collectively, these results indicate that concentrations of $\mathrm{NO}_{2}{ }^{-}$comparable to those found in inflammatory tissues and fluids are sufficient for MPO-dependent conversion of LDL into a high-uptake form. They also demonstrate that $\mathrm{HOCl}$ formation is not obligatory for conversion of LDL into a high-uptake form and that MPO (either isolated or derived from activated monocytes) utilizes $\mathrm{NO}_{2}^{-}$as substrate to modify LDL into a form that binds and is taken up and degraded by macrophages, even in the presence of plasma levels of $\mathrm{Cl}^{-}$. Because $\mathrm{MPO}$-generated reactive chlorinating species can modify protein and lipid components of lipoproteins $(29,31,52)$ but are not required for conversion of LDL into a stable high-uptake form by the MPO$\mathrm{H}_{2} \mathrm{O}_{2}-\mathrm{NO}_{2}^{-}$system of monocytes, subsequent studies characterizing the biochemical and biologic properties of LDL modified by MPO-generated nitrating intermediates were performed under $\mathrm{Cl}$-free conditions.

The MPO- $\mathrm{H}_{2} \mathrm{O}_{2}-\mathrm{NO}_{2}{ }^{-}$system promotes $\mathrm{LDL}$ protein nitration and induces $L D L$ lipid peroxidation. The nitrating intermediate formed by the MPO- $\mathrm{H}_{2} \mathrm{O}_{2}-\mathrm{NO}_{2}{ }^{-}$system is known to promote nitration of aromatic compounds and soluble proteins $(25,26)$; however, the products formed by 
a

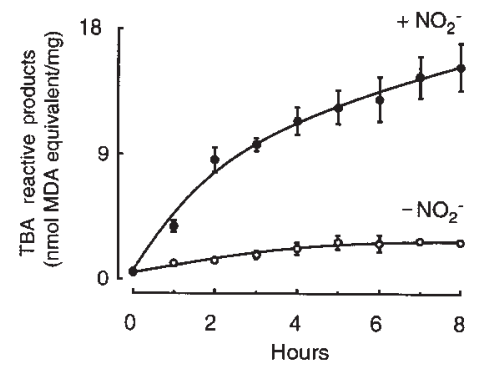

b

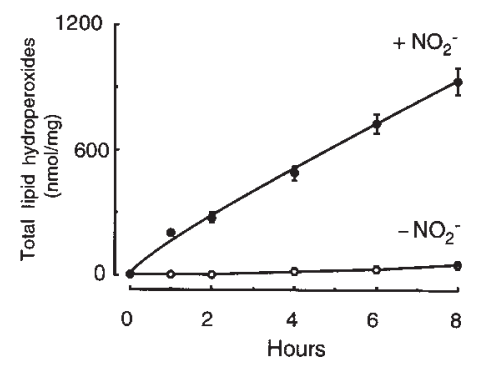

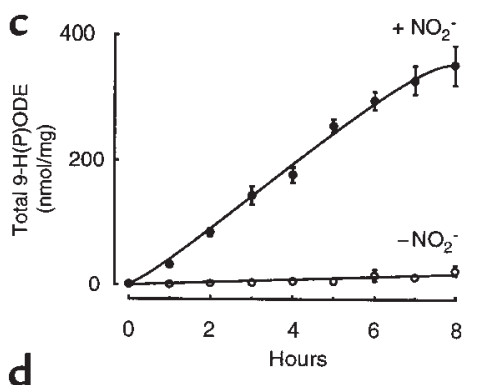

d

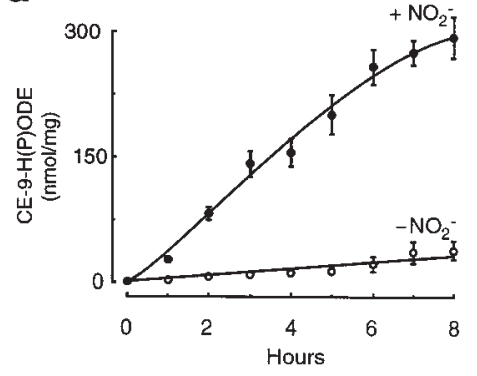

Figure 7

Quantification of multiple lipid oxidation products formed during LDL modification by the MPO- $\mathrm{H}_{2} \mathrm{O}_{2}-\mathrm{NO}_{2}{ }^{-}$system. LDL samples prepared for Figure 5 were analyzed for TBA reactive products (a), total lipid hydroperoxides (b), total 9$\mathrm{H}(\mathrm{P}) \mathrm{ODE}$ (c), and cholesteryl-9-H(P)ODE (d) as described in Methods. Data represent the mean \pm SD of 3 independent experiments (1 using $\left[{ }^{125} \mathrm{I}\right] \mathrm{LDL}$ as starting material and 2 using nonlabeled LDL as starting material). $+\mathrm{NO}_{2}{ }^{-}$(filled circles), LDL modified by MPO, an $\mathrm{H}_{2} \mathrm{O}_{2}$-generating system (GGOx), and $\mathrm{NO}_{2}^{-}$as described in Figure 5; - $\mathrm{NO}_{2}^{-}$(open circles), LDL modified by $\mathrm{MPO}$ and an $\mathrm{H}_{2} \mathrm{O}_{2}$-generating system (GGOx) as described in Figure 5. this reactive intermediate after incubation with lipids and lipoproteins have not yet been reported. This is of particular interest because nitrogen dioxide $\left(\mathrm{NO}_{2}\right)$, the one electron oxidation product of $\mathrm{NO}_{2}^{-}$, has been suggested to be the reactive nitrogen species formed during peroxidase-catalyzed oxidation of $\mathrm{NO}_{2}^{-}(25) . \mathrm{NO}_{2}$ is known to initiate lipid peroxidation both in vitro and after inhalation $(59,60)$; thus, exposure of LDL to the MPO- $\mathrm{H}_{2} \mathrm{O}_{2}-\mathrm{NO}_{2}{ }^{-}$system might also represent a mechanism to promote lipid peroxidation. To test this hypothesis, we determined whether markers of protein and lipid oxidation, such as LDL nitrotyrosine content and TBA reactive products, were increased in LDL preparations after exposure to $\mathrm{MPO}, \mathrm{NO}_{2}^{-}$, and an $\mathrm{H}_{2} \mathrm{O}_{2}$-generating system, using conditions that convert the lipoprotein into a high-uptake form for macrophages. Incubation of LDL with MPO-generated reactive nitrogen species resulted in concomitant conversion of the lipoprotein into a high-uptake form for elicited MPM, nitration of apo B-100 tyrosine residues, and induction of lipid peroxidation (Figure 4). Similar results (enhanced macrophage uptake) were also obtained using cultured hMDMs, resident MPMs, or THP-1 cells (data not shown). Acquisition of macrophage recognition, LDL protein nitration, and lipid peroxidation all demonstrated absolute requirements for $\mathrm{MPO}$ and $\mathrm{NO}_{2}{ }^{-}$, were inhibited by catalase and BHT, and occurred in the absence of metal ions (Figure 4). These results are consistent with a role for MPO, $\mathrm{H}_{2} \mathrm{O}_{2}$, and $\mathrm{NO}_{2}{ }^{-}$in producing a free radical intermediate that promotes nitration of apo B-100 tyrosyl residues, initiation of lipid peroxidation, and acquisition of macrophage recognition.

Multiple protein and lipid components of $L D L$ are modified by the $\mathrm{MPO}-\mathrm{H}_{2} \mathrm{O}_{2}-\mathrm{NO}_{2}^{-}$system during the acquisition of macrophage recognition. In the next set of experiments, we studied the time course of LDL conversion into a highuptake form after exposure to $\mathrm{MPO}, \mathrm{NO}_{2}^{-}$, and a low steady flux of $\mathrm{H}_{2} \mathrm{O}_{2}$ (Figure 5). In parallel, we also characterized the extent of lipoprotein modification by a variety of independent indices of protein oxidative dam- age (Figure 6) and lipid peroxidation (Figure 7). Statistically significant $(\mathrm{P}<0.01)$ increases in LDL uptake and degradation were observed with hMDMs and MPMs after a brief ( 2 hour) incubation of the lipoprotein with the complete MPO- $\mathrm{H}_{2} \mathrm{O}_{2}-\mathrm{NO}_{2}{ }^{-}$system (Figure 5). Cell recognition of the modified lipoprotein progressively increased in a nonlinear manner without indications of plateau after up to 8 hours of incubation. In stark contrast, no increase in macrophage uptake or degradation was observed in LDL incubated with $\mathrm{MPO}$ and $\mathrm{H}_{2} \mathrm{O}_{2}$ in the absence of $\mathrm{NO}_{2}{ }^{-}$over the entire time interval examined (Figure 5).

To characterize LDL preparations after exposure to MPO-generated reactive nitrogen species, we first examined several markers of protein modification during the same time interval over which macrophage recognition of the nitrated lipoprotein occurred (Figure 5). Nitrotyrosine was not observed during GC/MS analysis of native LDL; however, after brief exposure to the MPO$\mathrm{H}_{2} \mathrm{O}_{2}-\mathrm{NO}_{2}{ }^{-}$system, the nitrated amino acid was detected (Figure 6a). The nitrotyrosine content of $\mathrm{NO}_{2}-\mathrm{LDL}$ rose progressively with longer periods of incubation. The curvilinear nature of the plot suggests that alternative targets on LDL may be preferentially oxidized initially by the MPO-generated nitrating intermediate. One such protein target appears to be tryptophan residues, as incubation of LDL with the MPO- $\mathrm{H}_{2} \mathrm{O}_{2}-\mathrm{NO}_{2}{ }^{-}$system resulted in their rapid initial loss (Figure 6b). It has been demonstrated that marked increases in electrophoretic mobility and loss of $\mathrm{N}^{\varepsilon}$-amino groups of lysine are required for macrophage recognition of other modified forms of LDL, such as acetylated LDL, copper-oxidized LDL, and MDA-modified LDL $(61,62)$. However, after exposure to the MPO- $\mathrm{H}_{2} \mathrm{O}_{2}-\mathrm{NO}_{2}{ }^{-}$system, the content of free amine groups on LDL apo B-100 demonstrated only gradual progressive decreases with time (Figure 6c). After 2 hours of modification in the presence of $\mathrm{NO}_{2}^{-},<10 \%$ of lysine residues were modified (Figure 6c), yet statistically significant increases in LDL uptake and degradation were detected (Figure 5$)(P<0.01$ and $P<0.001$ for 


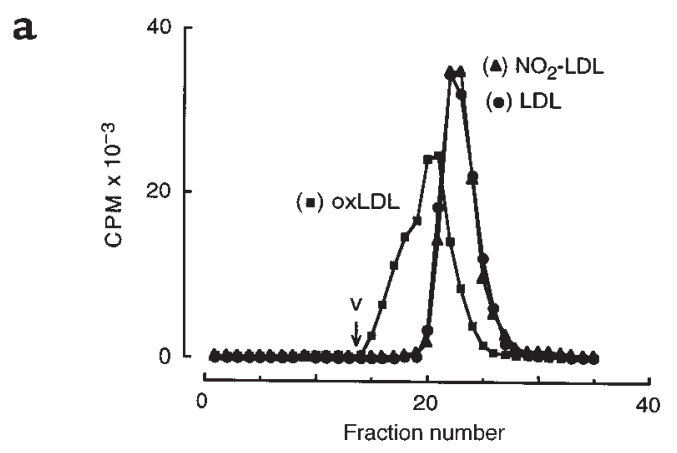

b

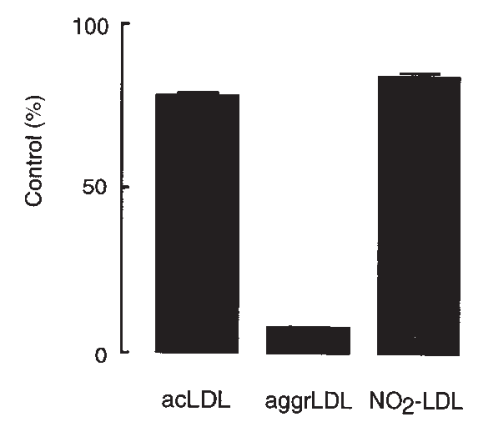

Figure 8

(a) Size exclusion chromatography. (b) The effect of cytochalasin D treatment on macrophage degradation of modified forms of LDL. (a) Native [ $\left.{ }^{125} \mathrm{I}\right] \mathrm{LDL}$ (LDL; filled circles), copper oxidized [ $\left.{ }^{125} \mathrm{I}\right] \mathrm{LDL}$ (oxLDL; filled squares), and [ $\left.{ }^{125} \mathrm{I}\right] \mathrm{LDL}$ modified by the complete MPO- $\mathrm{H}_{2} \mathrm{O}_{2}-\mathrm{NO}_{2}{ }^{-}$system $\left(\mathrm{NO}_{2}\right.$ - $\mathrm{LDL}$; filled triangles) were prepared and individually fractionated on a Sephacryl S400-HR column as described in Methods. The elution profiles of native and modified lipoproteins are shown. The void volume (v) of the column is indicated. (b) Acetylated [125I]LDL (acLDL), vortex-aggregated $\left[{ }^{125} \mid\right] \mathrm{LDL}$ (aggrLDL), and $\left[{ }^{125} \mid\right] \mathrm{LDL}$ modified by the complete MPO- $\mathrm{H}_{2} \mathrm{O}_{2}-\mathrm{NO}_{2}{ }^{-}$system $\left(\mathrm{NO}_{2}-\mathrm{LDL}\right)$ were prepared as described in Methods. The ${ }^{125}$-labeled lipoprotein preparations were then individually incubated $(5 \mu \mathrm{g} / \mathrm{mL})$ with thioglycollate-elicited MPMs at $37^{\circ} \mathrm{C}$ for 5 hours in the presence or absence of cytochalasin $\mathrm{D}(1 \mu \mathrm{g} / \mathrm{mL})$ in media supplemented with catalase $(300 \mathrm{nM})$ and BHT $(20 \mu \mathrm{M})$. Cellular degradation of lipoprotein was subsequently determined as described in Methods. Results are expressed as the percentage of lipoprotein degradation observed in the presence vs. absence of cytochalasin D treatment. Lipoprotein degradation by non-cytochalasin D-treated macrophages (control) exposed to acLDL, aggrLDL, and $\mathrm{NO}_{2}-\mathrm{LDL}$ preparations was $3.69 \pm 0.14,1.78 \pm 0.03$, and $1.49 \pm 0.08 \mu \mathrm{g} \mathrm{LDL}$ per milligram of cell protein, respectively. Data represent the mean \pm SD of triplicate determinations from a representative experiment performed in duplicate.

0 vs. 2 hours for hMDMs and MPMs, respectively). Consistent with these findings, only a modest progressive increase in the relative electrophoretic mobility (REM) of LDL was observed (Figure 6d), suggesting that only a slight increase in anionic charge of LDL occurred, despite significant macrophage recognition.

Exposure of LDL to MPO, $\mathrm{NO}_{2}^{-}$, and an $\mathrm{H}_{2} \mathrm{O}_{2}$-generating system resulted in rapid initiation of LDL lipid peroxidation (Figure 7). Even at the earliest time points examined, multiple lipid peroxidation products [TBA reactive products, total lipid hydroperoxides, total 9-H(P)ODE] including those of core lipids [cholesteryl-9-H(P)ODE] were formed, suggesting that the oxidant generated by the $\mathrm{MPO}-\mathrm{H}_{2} \mathrm{O}_{2}-\mathrm{NO}_{2}^{-}$system readily promotes hydrogen atom abstraction in unsaturated lipids (Figure 7). As with the protein markers of oxidation, production of lipid oxidation products was minimal in the absence of $\mathrm{NO}_{2}^{-}$. In a separate set of experiments, we examined $\alpha$-tocopherol levels vs. time in LDL preparations exposed to the MPO$\mathrm{H}_{2} \mathrm{O}_{2}-\mathrm{NO}_{2}{ }^{-}$system, as depicted in Figures 5-7. At 2 hours and 8 hours, $68 \pm 6.3 \%$ and $93 \pm 6.4 \%$, respectively, was consumed (mean $\pm \mathrm{SD} ; n=3$ independent experiments). Thus, modification of LDL by the MPO- $\mathrm{H}_{2} \mathrm{O}_{2}-\mathrm{NO}_{2}^{-}$system is accompanied by oxidation of multiple protein and lipid components of the lipoprotein and by significant depletion of lipid-soluble antioxidant species.

$\mathrm{LDL}$ modified by the MPO- $\mathrm{H}_{2} \mathrm{O}_{2}-\mathrm{NO}_{2}^{-}$system is not aggregated. Aggregation of LDL represents one mechanism for conversion of the lipoprotein into a high-uptake form (63, 64). A number of modifications, including exposure to reagent $\mathrm{HOCl}$ and other types of oxidation, result in LDL aggregation $(54,57,65,66)$. Preliminary studies suggested that $\mathrm{NO}_{2}$-LDL was not aggregated, because only negligible amounts $(<0.1 \%)$ of the lipoprotein failed to enter $0.5 \%$ agarose gels during electrophoresis and because no significant light scattering in $\mathrm{NO}_{2}$-LDL preparations was observed. To exclude more fully the possibility that small LDL aggregates formed during modification by the MPO$\mathrm{H}_{2} \mathrm{O}_{2}-\mathrm{NO}_{2}^{-}$system might contribute to the observed enhanced uptake and degradation by macrophages, additional experiments were performed. No evidence of particle aggregation in $\mathrm{NO}_{2}$-LDL preparations was observed during analysis by size exclusion chromatography (Figure 8a). The elution profile of $\mathrm{NO}_{2}-\mathrm{LDL}$ was identical to that of native LDL, whereas copper-oxidized LDL clearly demonstrated formation of particles of increased size (Figure 8a). We also examined the effect of cytochalasin D, an inhibitor of microfilament formation, on uptake and degradation of modified forms of lipoprotein by MPMs, as cytochalasin $\mathrm{D}$ has been effectively used as an inhibitor of phagocytosis of aggregated forms of LDL (66). Macrophage degradation of $\mathrm{NO}_{2}$-LDL was only modestly affected by cytochalasin D treatment (Figure 8b). Comparable results were seen with acetylated LDL, a prototypic ligand for scavenger receptor-mediated endocytosis (41). In contrast, degradation of vortex-aggregated LDL, which is internalized through a phagocytic mechanism (63), was inhibited by $>90 \%$ by cytochalasin D treatment (Figure $8 b$ ). Collectively, these results suggest that oxidation of LDL by the MPO- $\mathrm{H}_{2} \mathrm{O}_{2}-\mathrm{NO}_{2}{ }^{-}$system does not promote aggregation of the lipoprotein; moreover, they also suggest that the observed enhanced uptake of $\mathrm{NO}_{2}$ - $\mathrm{LDL}$ is not the result of phagocytosis of the modified lipoprotein.

Macrophage binding of LDL modified by the MPO- $\mathrm{H}_{2} \mathrm{O}_{2}^{-}$ $\mathrm{NO}_{2}{ }^{-}$system is saturable and specific. The lack of lipoprotein aggregation after modification by the $\mathrm{MPO}-\mathrm{H}_{2} \mathrm{O}_{2}-\mathrm{NO}_{2}^{-}$ system, and the inability of cytochalasin D to significantly inhibit macrophage uptake and degradation of $\mathrm{NO}_{2}$-LDL, suggested that cellular recognition was likely mediated through a receptor-mediated process. To test this hypothesis, we examined whether [ $\left.{ }^{125} \mathrm{I}\right] \mathrm{NO}_{2}$ LDL binding and degradation by MPMs were saturable and specific. Macrophage binding of LDL that was nitrated by the complete $\mathrm{MPO}-\mathrm{H}_{2} \mathrm{O}_{2}-\mathrm{NO}_{2}{ }^{-}$system was saturable (Figure 9a). Under the conditions used, the half-maximal concentration for $\left[{ }^{125} \mathrm{I}\right] \mathrm{NO}_{2}$-LDL binding to macrophages was $\sim 10 \mu \mathrm{g} / \mathrm{mL}$ (20 $\mathrm{nM}$ lipoprotein), 
a

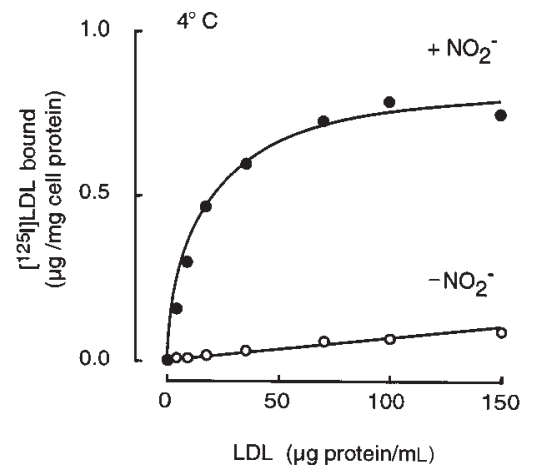

b

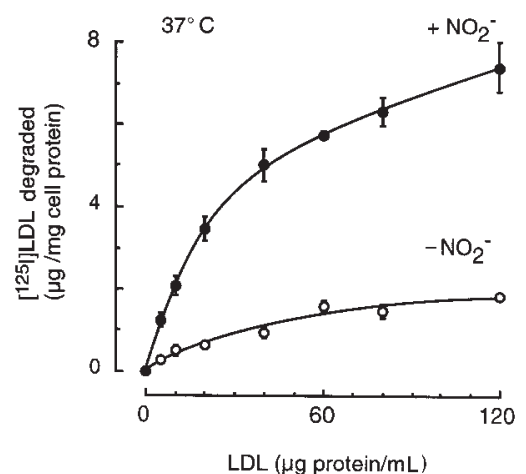

Figure 9

Concentration dependence of macrophage binding (a) and degradation (b) of $\mathrm{LDL}$ modified by the MPO- $\mathrm{H}_{2} \mathrm{O}_{2}-\mathrm{NO}_{2}{ }^{-}$system. (a) [ $\left.{ }^{125} \mathrm{I}\right] \mathrm{LDL}$ was modified in the presence of MPO and an $\mathrm{H}_{2} \mathrm{O}_{2}$-generating system (GGOx) in either the presence ( $\mathrm{NO}_{2}^{-}$; filled circles) or absence $\left(-\mathrm{NO}_{2}^{-}\right.$; open circles) of $\mathrm{NO}_{2}{ }^{-}$in sodium phosphate buffer $(50 \mathrm{mM}, \mathrm{pH} 7.0)$ supplemented with DTPA $(100 \mu \mathrm{M})$ as described in Methods. Thioglycollateelicited MPM binding (a) and degradation (b) of the indicated concentrations of lipoproteins were then assessed as described in Methods. Data represent the mean of duplicate determinations (binding studies) or the mean \pm SD of triplicate determinations (degradation studies). Similar results were observed in 3 independent experiments.

confirming that the cells recognize $\mathrm{NO}_{2}$-LDL with high affinity. Macrophage binding of $\mathrm{NO}_{2}$-LDL was also specific because binding of LDL exposed to MPO and $\mathrm{H}_{2} \mathrm{O}_{2}$ in the absence of $\mathrm{NO}_{2}^{-}$was negligible (Figure 9a). Moreover, coincubation of $\left[{ }^{125} \mathrm{I}\right] \mathrm{NO}_{2}$-LDL either with a 40fold excess of nonlabeled native LDL or with LDL modified in the presence of $\mathrm{MPO}$ and $\mathrm{H}_{2} \mathrm{O}_{2}$ without $\mathrm{NO}_{2}{ }^{-}$ failed to significantly block ( $\leq 10 \%$ inhibition) macrophage recognition of the modified lipoprotein. In contrast, competition studies examining $\left[{ }^{125} \mathrm{I}\right] \mathrm{NO}_{2}-\mathrm{LDL}$ binding, uptake, and degradation to macrophages demonstrated that excess nonlabeled $\mathrm{NO}_{2}$ - $\mathrm{LDL}$ was an effective competitor (>70\% inhibition). The concentration dependence of $\mathrm{NO}_{2}$-LDL degradation (Figure $9 \mathrm{~b}$ ) by MPMs (at $37^{\circ} \mathrm{C}$ ) was also examined and demonstrated comparable hyperbolic plots, consistent with uptake and degradation of the modified lipoprotein through a saturable process. In contrast, cell-mediated uptake and degradation of LDL modified by MPO and $\mathrm{H}_{2} \mathrm{O}_{2}$ in the absence of $\mathrm{NO}_{2}{ }^{-}$were minimal (Figure $9 \mathrm{~b}$ ). Collectively, these results are consistent with macrophage recognition of $\mathrm{NO}_{2}$-LDL through a specific high-affinity receptor-mediated process.
Macrophage recognition of $L D L$ modified by the $M P O-\mathrm{H}_{2} \mathrm{O}_{2}$ $\mathrm{NO}_{2}{ }^{-}$system occurs through a pathway independent of the class A type I scavenger receptor. Increased macrophage binding, uptake, and degradation of [125] ${ }^{12 D L}$ modified by the MPO- $\mathrm{H}_{2} \mathrm{O}_{2}-\mathrm{NO}_{2}{ }^{-}$system, which is saturable and not inhibited by excess native LDL, suggests that the nitrated lipoprotein is being bound and internalized by a receptor that is not the LDL receptor. To characterize the nature of the macrophage receptor mediating recognition of $\mathrm{NO}_{2}-\mathrm{LDL}$, we initially performed competition studies using known inhibitors of scavenger receptor class A. Excess polyanionic inhibitors such as polyinosinic acid, polyguanylate, dextran sulfate, and fucoidan all failed to inhibit MPM uptake of $\mathrm{NO}_{2}-\mathrm{LDL}$ by $>50 \%$ (data not shown). These results suggested that scavenger receptor class $\mathrm{A}$, if involved in $\mathrm{NO}_{2}$-LDL recognition, could only partially account for the recognition of this modified form of LDL. To assess further whether the classic scavenger receptor participates in the recognition of $\mathrm{NO}_{2}$-LDL, we examined the uptake and degradation of the nitrated lipoprotein using $\mathrm{CHO}$ cells expressing mSR-AI. CHO-mSR-AI demonstrated significant uptake and degradation of both acetylated LDL and copper-oxidized LDL when compared with control vector-transfected $\mathrm{CHO}$ cells, as reported previously (56). In contrast, there was only a negligible increase in the uptake and degradation of $\mathrm{NO}_{2}$-LDL by CHO-mSR-AI cells compared with control vector-transfected cells (Figure 10). Although the difference was significant ( $\mathrm{P}<$ $0.05)$, expression of mSR-AI only augmented cell uptake of $\mathrm{NO}_{2}$-LDL by $\sim 20 \%$ over basal levels. Thus, the scavenger receptor SR-AI does not appear to play an important role in macrophage recognition of LDL modified by MPO-generated reactive nitrogen species.

$\mathrm{LDL}$ modified by the MPO- $\mathrm{H}_{2} \mathrm{O}_{2}-\mathrm{NO}_{2}^{-}$system promotes macrophage cholesteryl ester synthesis, lipid loading, and foam cell formation. Protein nitration, induction of lipid peroxidation, and conversion of the lipoprotein into a highuptake form are all properties consistent with conversion of LDL into a proatherogenic form. To determine whether LDL modification by MPO-generated reactive nitrogen species might contribute to cholesterol accumulation in macrophages, a critical process in lesion development, we first evaluated the ability of $\mathrm{NO}_{2}-\mathrm{LDL}$ to stimulate cholesteryl ester biosynthesis by MPMs. $\mathrm{NO}_{2}$-LDL markedly stimulated $\left[{ }^{14} \mathrm{C}\right]$ oleate incorporation into cellular cholesteryl ester pools in MPMs (Figure 11a). In contrast, additions or deletions to the complete system that prevented LDL protein nitration, lipid peroxidation, and macrophage recognition all resulted in ablation of macrophage cholesteryl ester formation from exogenous modified lipoprotein (compare Figures 4 and 11). In a parallel set of experiments, the ability of $\mathrm{NO}_{2}$-LDL to promote cellular accumulation of intracellular sterol pools was examined. Again, only LDL modified in the presence of each component of the complete MPO- $\mathrm{H}_{2} \mathrm{O}_{2}$ $\mathrm{NO}_{2}^{-}$system, but not in the presence of catalase or BHT, promoted significant increases in free and esterified cholesterol content of macrophages (Figure 11).

In a final set of experiments, we examined whether stimulation of cholesteryl ester biosynthesis and cellular lipid accumulation in macrophages incubated with 




Figure 10

Uptake of ${ }^{125}$-labeled lipoproteins by $\mathrm{CHO}$ cells transfected with the murine scavenger receptor class A type I. Confluent $\mathrm{CHO}$ cells expressing the murine scavenger receptor class A type I (white bars) or control vector-transfected parental $\mathrm{CHO}$ cells that lack the LDL receptor (black bars) were incubated for 5 hours at $37^{\circ} \mathrm{C}$ with $5 \mu \mathrm{g} / \mathrm{mL}$ of the indicated 125 -labeled lipoproteins prepared as described in Methods. Cellular uptake of modified lipoproteins was then determined as described in Methods. Data represent the mean \pm SD of triplicate determinations. Similar results were observed in 3 independent experiments. ${ }^{*} P<0.05$ vs. control vector-transfected parental $\mathrm{CHO}$ cells; ${ }^{*} P<0.001 \mathrm{vs}$. control vector-transfected parental CHO cells. acLDL, acetylated LDL; LDL, native $\mathrm{LDL} ; \mathrm{mSR}-\mathrm{Al}, \mathrm{CHO}$ cells expressing the murine scavenger receptor class A type I; + $\mathrm{NO}_{2}-\mathrm{LDL}$, LDL modified by the complete $\mathrm{MPO}-\mathrm{H}_{2} \mathrm{O}_{2}-$ $\mathrm{NO}_{2}{ }^{-}$system; - $\mathrm{NO}_{2}-\mathrm{LDL}, \mathrm{LDL}$ modified by the complete system in the absence of $\mathrm{NO}_{2}^{--}$; oxLDL, copper oxidized (5 hours) LDL.

$\mathrm{NO}_{2}$-LDL resulted in the formation of lipid-laden foam cells, an early cellular event in the atherosclerotic process. Thioglycollate-elicited MPMs were incubated for 72 hours with either native LDL (negative control), acetylated $\mathrm{LDL}$ (positive control), $\mathrm{NO}_{2}$ - $\mathrm{LDL}$, or $\mathrm{LDL}$ exposed to $\mathrm{MPO}$ and $\mathrm{H}_{2} \mathrm{O}_{2}$ in the absence of $\mathrm{NO}_{2}^{-}$, and then microscopically examined after neutral lipid staining with oil red O. LDL nitrated by MPO promoted massive cholesterol deposition in macrophages (Figure 12). Moreover, the oil red $\mathrm{O}$-positive staining of $\mathrm{NO}_{2}-\mathrm{LDL}$ demonstrated comparable intensity to that observed in macrophages exposed to an equivalent level of exhaustively acetylated LDL (Figure 12). The total cholesterol content (cholesteryl ester + free cholesterol) of macrophages exposed to equivalent levels of $\mathrm{NO}_{2}-\mathrm{LDL}$ and exhaustively acetylated LDL was $189 \pm 13 \mu \mathrm{g} / \mathrm{mg}$ cell protein and $333 \pm 100 \mu \mathrm{g} / \mathrm{mg}$ cell protein, respectively (mean $\pm \mathrm{SD} ; n=3$ ). Interestingly, the lipid droplets within the cytoplasm of the $\mathrm{NO}_{2}$-LDL-treated cells were more punctate and diffusely spread than those observed with acetylated LDL (Figure 13), suggesting that the intracellular processing of nitrated and acetylated lipoproteins differs. In contrast, cells incubated with either native $\mathrm{LDL}$ or with $\mathrm{LDL}$ exposed to MPO and $\mathrm{H}_{2} \mathrm{O}_{2}$ in the absence of $\mathrm{NO}_{2}^{-}$were devoid of oil red O-positive droplets (Figure 12). Collectively, these results demonstrate that LDL modification by MPOgenerated reactive nitrogen species converts the lipoprotein into a form that promotes extensive lipid loading of macrophages and foam cell formation.

\section{Discussion}

Reactive nitrogen species have been implicated in promoting oxidative damage of LDL and tissues in atherosclerosis $(16,17)$. However, neither the pathways for nitrating LDL in vivo nor the biologic consequences of these reactions are established. The results of the current study demonstrate that nitrating intermediates formed by the MPO- $\mathrm{H}_{2} \mathrm{O}_{2}-\mathrm{NO}_{2}{ }^{-}$system of monocytes mediate LDL protein nitration, initiate LDL lipid peroxidation, and convert the lipoprotein into a form that promotes cholesterol deposition in macrophages and foam cell formation.

Despite intense interest in the role of reactive nitrogen species in inflammatory injury and vascular disease, few studies have examined the effects of nitrating intermediates on LDL recognition by macrophages. LDL incubated with SIN-1, a compound that spontaneously decomposes to generate comparable rates of $\mathrm{O}_{2}{ }^{-}$and $\mathrm{NO}$ production, results in increased levels of lipid peroxidation products but does not generate a high-uptake form of LDL (8, 13). Studies examining the effects of modulators of NO synthesis on phorbol ester-stimulated MPMs are consistent with NO playing a protective role, as increased NO production inhibited, and decreased NO production promoted, LDL oxidation and conversion into a high-uptake form (8). LDL exposed to reagent $\mathrm{ONOO}^{-}$has been shown to promote macrophage cholesteryl ester biosynthesis (13). However, the mechanism(s) of cell recognition of $\mathrm{ONOO}^{-}$-modified lipoproteins has not yet been examined. Several observations suggest that macrophage recognition of ONOO--modified LDL occurs through mechanisms distinct from those involved with LDL modified by the MPO- $\mathrm{H}_{2} \mathrm{O}_{2}-\mathrm{NO}_{2}{ }^{-}$system. Stimulation of macrophage cholesteryl oleate synthesis by $\mathrm{ONOO}^{-}$-treated LDL requires millimolar quantities of oxidant and extensive LDL modification ( $60 \%$ lysine modification, REM > 2) (13). In contrast, modification into a high-uptake form by $\mathrm{MPO}$-generated nitrating intermediates requires only low levels of $\mathrm{H}_{2} \mathrm{O}_{2}$, results in minimal depletion of free lysine residues, and only modestly enhances lipoprotein REM (Figure 6). Moreover, modification of LDL with high levels of $\mathrm{ONOO}^{-}$results in lipoprotein aggregation, as judged by light scattering and size exclusion chromatography (D. Schmitt and S.L. Hazen, unpublished study); thus, cellular uptake mechanisms of ONOO--modified LDL may be via phagocytosis of aggregates. Similarly, LDL aggregation (and hence, phagocytosis by macrophages) has been demonstrated after exposure of LDL to an atmosphere containing $\mathrm{NO}_{2}$ gas (67), vortexed mixtures of $\mathrm{HOCl}$ and $\mathrm{NO}_{2}^{-}$(58), and millimolar levels of $\mathrm{NO}_{2}{ }^{-}$for prolonged periods (68).

In contrast, multiple lines of evidence suggest that macrophage uptake of LDL modified by $\mathrm{MPO}, \mathrm{H}_{2} \mathrm{O}_{2}$, and $\mathrm{NO}_{2}^{-}$occurs via a pathway involving receptor-mediated endocytosis rather than phagocytosis. Binding of $\mathrm{NO}_{2}-$ LDL to macrophages occurred through a high-affinity, saturable, and specific interaction - characteristics of a receptor-mediated process. Moreover, uptake and degradation of the modified lipoprotein were saturable, unlike bulkphase phagocytosis of lipoprotein aggregates $(63,64)$. Competition studies examining [ $\left.{ }^{125} \mathrm{I}\right] \mathrm{NO}_{2}$-LDL binding, uptake, and degradation by macrophages further confirm 
a

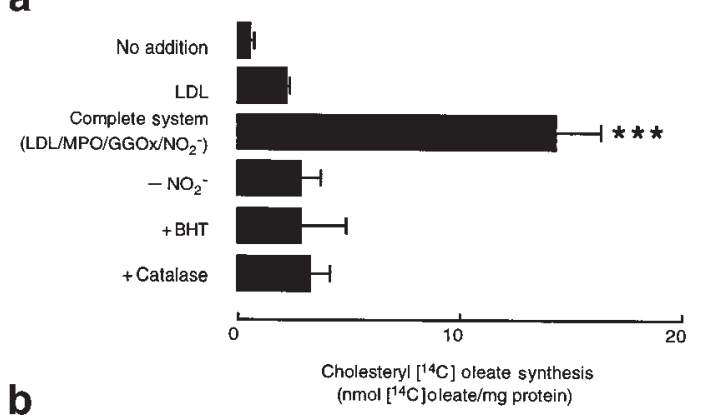

b

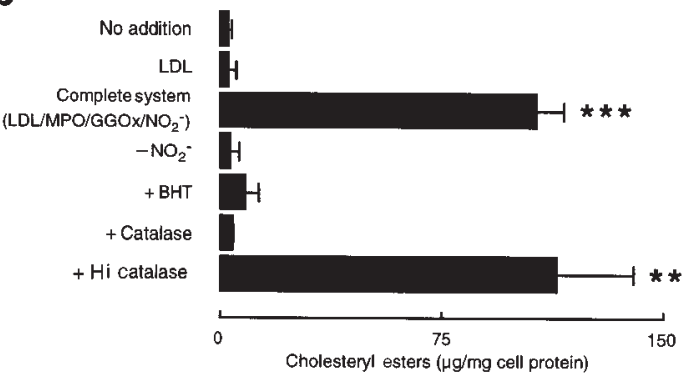

C

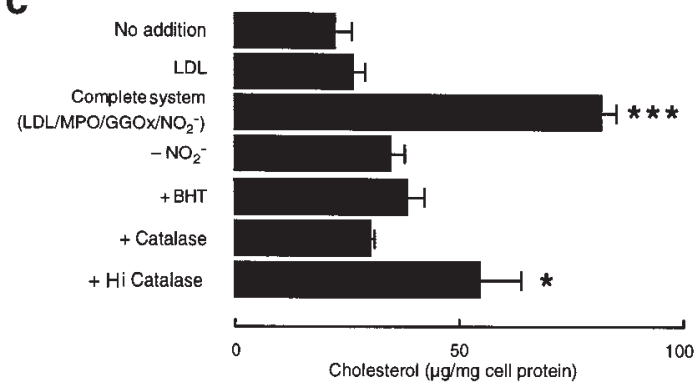

\section{Figure 11}

Cholesteryl oleate synthesis (a), cholesteryl ester mass (b), and cholesterol mass (c) of cells exposed to LDL modified by the MPO- $\mathrm{H}_{2} \mathrm{O}_{2}-\mathrm{NO}_{2}-$ system. [ $\left.\left.{ }^{125}\right]\right] \mathrm{LDL}(0.2 \mathrm{mg} / \mathrm{mL})$ was incubated with isolated human MPO $(30 \mathrm{nM})$, glucose $(100 \mu \mathrm{M})$, glucose oxidase $(20 \mathrm{ng} / \mathrm{mL})$, and $\mathrm{NO}_{2}{ }^{-}(500$ $\mu \mathrm{M})$ in sodium phosphate buffer $(50 \mathrm{mM}, \mathrm{pH} 7.0)$ supplemented with DTPA $(100 \mu \mathrm{M})$ (complete system) or the indicated additions or deletions. Lipoproteins were then incubated with thioglycollate-elicited MPMs, and the extent of cholesteryl $\left[{ }^{14} \mathrm{C}\right]$ oleate formation (a), cellular cholesteryl ester mass (b), and free cholesterol mass (c) was determined as described in Methods. Data represent the mean \pm SD of triplicate determinations. Similar results were observed in 3 independent experiments. ${ }^{*} P<0.05 ;{ }^{*} P<0.01 ;{ }^{*}{ }^{*} P<0.001$ for comparison vs. LDL modified by MPO and an $\mathrm{H}_{2} \mathrm{O}_{2}$-generating system only $\left(-\mathrm{NO}_{2}{ }^{-}\right)$. No significant cholesteryl $\left[{ }^{14} \mathrm{C}\right]$ oleate formation or increase in cholesteryl ester or free cholesterol mass above basal values was observed in LDL preparations modified by the complete system in the absence of either MPO or GGOx. Hi catalase, heat-inactivated catalase.

the specificity of the interaction because excess nonlabeled $\mathrm{NO}_{2}$-LDL was an effective competitor, but native LDL and LDL modified in the presence of MPO and $\mathrm{H}_{2} \mathrm{O}_{2}$ without $\mathrm{NO}_{2}^{-}$were not. Finally, lipoprotein aggregation during oxidative modification by the $\mathrm{MPO}-\mathrm{H}_{2} \mathrm{O}_{2}-\mathrm{NO}_{2}{ }^{-}$system was excluded by a variety of methods including size exclusion chromatography, light scattering, gel electrophoresis, and cytochalasin D treatment of macrophages.

The distinction between macrophage uptake and degradation of an aggregated lipoprotein compared with a monomeric/soluble oxidized lipoprotein also underscores the unexpected findings observed when examining the potential role of MPO-generated chlorinating and nitrating intermediates in conversion of LDL into a high-uptake form. Previous studies reported by Hazell et al. (57) noted that LDL treatment with reagent $\mathrm{HOCl}$ becomes aggregated and, like other aggregated forms of lipoproteins, promotes intracellular lipid accumulation in macrophages (54). However, in the present study, LDL incubated with either activated human monocytes in $\mathrm{Cl}^{-}$-containing media (Figure 1) or an HOCl-generating system (MPO, $\mathrm{GGOx}$, and $\mathrm{Cl}^{-}$; Figure 2) was not converted into a stable high-uptake form. These results suggest that direct addition of reagent $\mathrm{HOCl}$ and in situ formation of $\mathrm{HOCl}$ by the MPO- $\mathrm{H}_{2} \mathrm{O}_{2}-\mathrm{Cl}^{-}$system of phagocytes modify LDL in different ways. A similar conclusion was reached in a recent mass spectrometric study examining peptide oxidation products in tryptic digests of apo $\mathrm{B}-100$ from LDL exposed to either reagent $\mathrm{HOCl}$ or the $\mathrm{MPO}-\mathrm{H}_{2} \mathrm{O}_{2}-\mathrm{Cl}^{-}$system (69). Such a difference might be observed if MPO binds directly to LDL and locally delivers oxidant to select sites on the lipoprotein particle. Alternatively, certain targets for oxidation on LDL may only be modified in the presence of high local concentrations of oxidants produced during bolus addition in vitro, but that otherwise might not be observed under more physiological conditions. Indeed, under the conditions of a low steady flux of $\mathrm{H}_{2} \mathrm{O}_{2}$ used in the present study, no significant LDL aggregation was observed during exposure of the lipoprotein to the MPO$\mathrm{H}_{2} \mathrm{O}_{2}-\mathrm{Cl}^{-}$system. In contrast, LDL aggregation and conversion into a particle ingested by phagocytosis was observed after addition of reagent $\mathrm{HOCl}$ or after bolus addition of $\mathrm{H}_{2} \mathrm{O}_{2}$ to $\mathrm{LDL}$ incubated in the presence of $\mathrm{MPO}$ and $\mathrm{Cl}^{-}$(E. Podrez et al., unpublished study). The results of the present study do not rule out formation of a labile oxidation product from the $\mathrm{MPO}-\mathrm{H}_{2} \mathrm{O}_{2}-\mathrm{Cl}^{-}$system (e.g., $\mathrm{N}$-monochloramines) that is subsequently repaired (57) during incubations with cells. Whether such a labile modified form of LDL is a ligand for macrophages, and might thus play a role in LDL uptake in vivo in circumstances in which repair processes might become depleted, cannot be excluded. Taken together, the results of the present study suggest that under conditions in which only a low flux of $\mathrm{H}_{2} \mathrm{O}_{2}$ is formed, MPO-generated nitrating intermediates are more effective than chlorinating intermediates in promoting oxidative conversion of LDL into a stable high-uptake form.

Because of the high concentrations of $\mathrm{Cl}^{-}$in biologic matrices, reactive chlorinating species have routinely been thought to be the predominant oxidant formed by the $\mathrm{MPO}-\mathrm{H}_{2} \mathrm{O}_{2}$ system of phagocytes in vivo (21-24). However, the results of the present study clearly demonstrate that MPO (either isolated or derived from activated monocytes) utilizes $\mathrm{NO}_{2}{ }^{-}$to convert $\mathrm{LDL}$ into a form that binds to, and is taken up and degraded by, macrophages, even in the presence of plasma levels of $\mathrm{Cl}^{-}$. Furthermore, these results also demonstrate that $\mathrm{HOCl}$ formation is not obligatory for MPO- and $\mathrm{NO}_{2}{ }^{-}$-dependent conversion of LDL into a high-uptake form. Consequently, many of the experiments described in the present study were performed with no $\mathrm{Cl}^{-}$present during the oxidation reaction because from a mechanistic standpoint, it is then possible to demonstrate that both the alterations in the biologic 


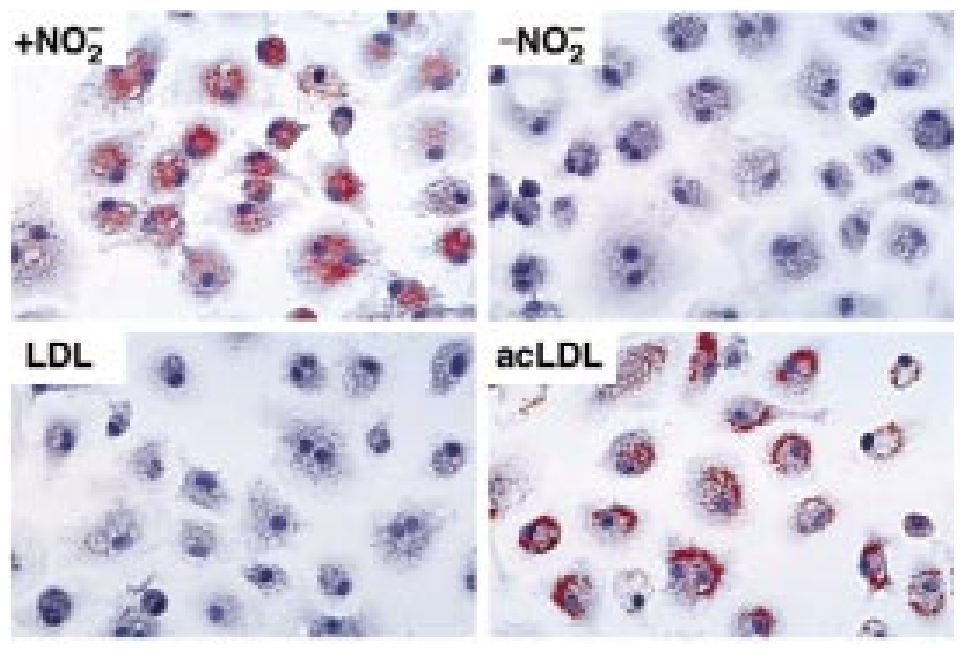

\section{Figure 12}

Macrophage foam cell formation by exposure to LDL modified by the MPO- $\mathrm{H}_{2} \mathrm{O}_{2}-\mathrm{NO}_{2}{ }^{-}$system. Thioglycollate-elicited MPMs were grown for 48 hours in RPMI-1640 containing $10 \%$ FBS. Cells were then incubated for 72 hours in the same media containing catalase $(100 \mathrm{nM})$, BHT $(20 \mu \mathrm{M})$, and vitamin $\mathrm{E}(20 \mu \mathrm{M})$ in the presence of the following lipoprotein preparations $(50 \mu \mathrm{g} / \mathrm{mL})$ : LDL $(0.2 \mathrm{mg} / \mathrm{mL})$ previously incubated with isolated human MPO $(30 \mathrm{nM})$, glucose $(100 \mu \mathrm{M})$, and glucose oxidase $(20 \mathrm{ng} / \mathrm{mL})$ in sodium phosphate buffer $(50 \mathrm{mM}, \mathrm{pH} 7.0)$ supplemented with DTPA $(100 \mu \mathrm{M})$ at $37^{\circ} \mathrm{C}$ for 8 hours in the presence $\left(+\mathrm{NO}_{2}{ }^{-}\right)$and absence $\left(-\mathrm{NO}_{2}{ }^{-}\right)$of $\mathrm{NO}_{2}{ }^{-}(500 \mu \mathrm{M})$, native LDL (LDL), and acetylated LDL (acLDL). Media containing the appropriate modified lipoproteins were exchanged after 24-hour incubation. Cells were fixed with $4 \%$ formaldehyde and stained with hematoxylin and oil red $\mathrm{O}$. Original magnification: $\times 300$.

end points examined (e.g., binding, cell association, uptake, degradation, sterol accumulation) and the oxidation products formed (e.g., nitrotyrosine, various lipid peroxidation products) are the result of an oxidant species derived from MPO-dependent oxidation of $\mathrm{NO}_{2}^{-}$. Although the nitrating intermediate(s) formed by the reaction of $\mathrm{NO}_{2}{ }^{-}$with the $\mathrm{MPO}-\mathrm{H}_{2} \mathrm{O}_{2}$ system has not been identified, $\mathrm{NO}_{2}$ (the one electron oxidation product of $\mathrm{NO}_{2}{ }^{-}$) and $\mathrm{NO}_{2} \mathrm{Cl}$ (formed by reaction of $\mathrm{HOCl}$ with $\mathrm{NO}_{2}^{-}$) have been implicated $(25,26,33)$. Thus, under physiological conditions in which both $\mathrm{Cl}^{-}$and $\mathrm{NO}_{2}{ }^{-}$are present, a variety of halogenating and nitrating intermediates may be formed by MPO $(24,25,30,33,52)$. The product(s) of the MPO- $\mathrm{H}_{2} \mathrm{O}_{2}-\mathrm{NO}_{2}{ }^{-}$system is anticipated to be particularly effective at converting LDL into a high-uptake form for intimal macrophages.

Despite evidence suggesting that a receptor-mediated pathway is involved in macrophage recognition of $\mathrm{NO}_{2}-$ $\mathrm{LDL}$, the identity of the receptor and ligand mediating the interaction is unknown. Experiments using $\mathrm{CHO}$ cells expressing mSR-AI demonstrated no difference in $\mathrm{NO}_{2}-$ LDL binding, uptake, or degradation when compared with control vector-transfected $\mathrm{CHO}$ cells, strongly suggesting that class A type I scavenger receptor does not participate in recognition of the nitrated lipoprotein. This lack of recognition is consistent with the relatively low level of apo B-100 lysine blockage and REM observed (Fig- ure 6) compared with that required for recognition of other modified forms of $\operatorname{LDL}(61,62)$. Future studies identifying the nature of the ligand(s) and receptor(s) mediating macrophage recognition of $\mathrm{NO}_{2}-\mathrm{LDL}$ are warranted.

The ability of modified forms of LDL to promote accumulation of cellular cholesteryl esters has been widely accepted as an index of the atherogenic potential of a lipoprotein. While our studies show that incubation of LDL with activated monocytes in the presence $\mathrm{NO}_{2}{ }^{-}$transforms the lipoprotein into a high-uptake form, the biologic significance of this type of modification in vivo is not yet established. All of the in vitro cell experiments in the present study were performed under serum-free conditions. Whether or not the MPO- $\mathrm{H}_{2} \mathrm{O}_{2}-\mathrm{NO}_{2}{ }^{-}$system of monocytes effectively modifies LDL in a more physiological, serum/plasma- containing milieu remains to be explored. However, considerable evidence suggests that MPO may contribute to nitration of LDL in human atheroma because all of the components of the MPO$\mathrm{H}_{2} \mathrm{O}_{2}-\mathrm{NO}_{2}{ }^{-}$system are present and available for lipoprotein and tissue oxidative damage in human lesions, and products of this pathway - e.g., nitrotyrosine $(16,17)$, dityrosine (70), and lipid hydroperoxides $(43,71)$ - are enriched in human lesions. Indeed, immunohistochemical staining demonstrates that MPO colocalizes with lipid-laden macrophages (28), and our recent mass spectrometric studies demonstrate that chlorotyrosine, a spe-
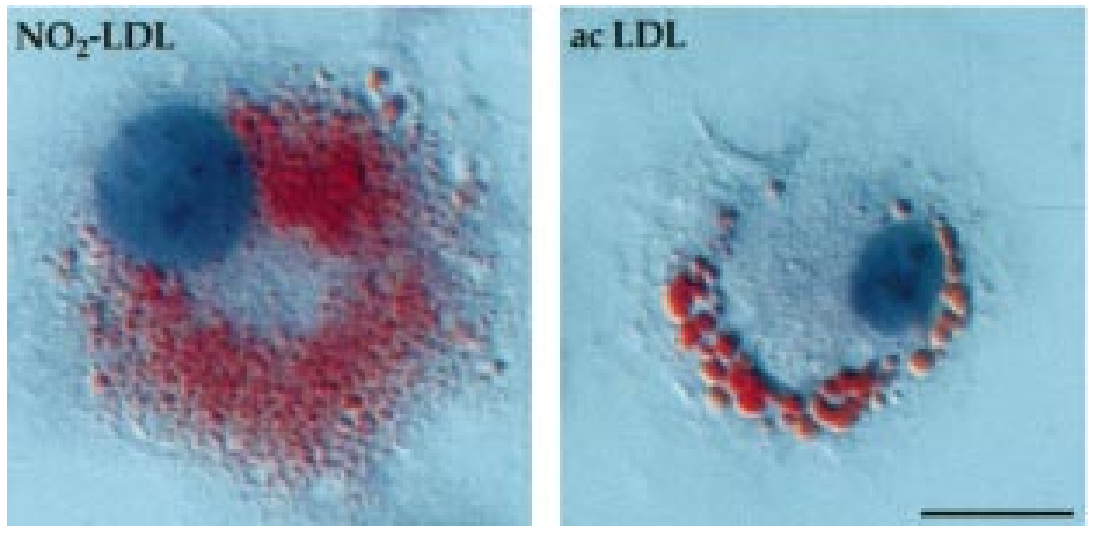

\section{Figure 13}

High-power magnification view of macrophage foam cells formed by exposure to $\mathrm{LDL}$ modified by the MPO- $\mathrm{H}_{2} \mathrm{O}_{2-}$ $\mathrm{NO}_{2}{ }^{-}$system and acetylated $\mathrm{LDL}$ (acLDL). Differential interference contrast microscopy of hematoxylin and oil red O-stained thioglycollate-elicited MPMs exposed to $\mathrm{NO}_{2}$ - $\mathrm{LDL}$ and acLDL as in Figure 12. Scale bar: $10 \mu \mathrm{m}$. 
cific marker for MPO-dependent protein damage by chlorinating intermediates $(24,72,73)$, is significantly enriched in LDL recovered from human aortic lesions and atherosclerotic intima (29). Thus, catalytically active MPO and sufficient levels of $\mathrm{H}_{2} \mathrm{O}_{2}$ to generate reactive oxidants with the enzyme are present in human vascular tissues. Moreover, the low rate of $\mathrm{H}_{2} \mathrm{O}_{2}$ flux used for lipoprotein modification in this study is less than that generated by circulating levels of leukocytes activated in suspension (74) or on biologic surfaces (75). Furthermore, although the actual concentration of $\mathrm{NO}_{2}{ }^{-}$in arterial intima is not known, the concentration of $\mathrm{NO}_{2}^{-}$required for MPOdependent conversion of LDL into a high-uptake form is well within the range of that observed in other inflammatory fluids and tissues (35-37). Finally, the levels of nitrotyrosine observed in apo B-containing LDL-like particles recovered from human atherosclerotic lesions (17) are several-fold greater than those observed in $\mathrm{NO}_{2}$-LDL preparations, which are avidly taken up and degraded by macrophages. Thus, MPO-generated nitrating intermediates may represent a physiologically plausible mechanism for promoting protein nitration, lipid peroxidation, and cholesterol deposition in macrophage-rich human atherosclerotic tissues.

\section{Acknowledgments}

We thank D.M. Driscoll and G.M. Chisolm for thoughtful comments and criticisms, H.L. Copeland for advice on statistical analyses, and P.A. Cohen and M.K. Cathcart for generously providing human monocytes used for the preparation of hMDMs in this study. We also thank Monty Krieger for generously providing $\mathrm{CHO}$ cells transfected with mSRA-1. This work was supported in part by a Scientist Development Grant from the American Heart Association and by National Institutes of Health grants HL-61878 and HL-62526 (to S.L. Hazen) and HL-53315 (to H.F. Hoff).

1. Witztum, J.L., and Steinberg, D. 1991. Role of oxidized low density lipoprotein in atherogenesis. J. Clin. Invest. 88:1785-1792.

2. Steinbrecher, U.P., Zhang, H.F., and Lougheed, M. 1990. Role of oxidatively modified LDL in atherosclerosis. Free Radic. Biol. Med. 9:155-168.

3. Chisolm, G.M., and Penn, M.S. 1998. Oxidized lipoproteins and atherosclerosis. In Atherosclerosis and coronary artery disease. V. Fuster, R. Ross, and E. J. Topol, editors. Lippincott-Raven Publishers. Philadelphia, PA. 129-149.

4. Berliner, J.A., et al. 1995. Atherosclerosis: basic mechanisms. Oxidation, inflammation, and genetics. Circulation. 91:2488-2496.

5. Steinberg, D. 1997. Lewis A. Conner Memorial Lecture. Oxidative modification of LDL and atherogenesis. Circulation. 95:1062-1071.

6. Heinecke, J.W. 1998. Oxidants and antioxidants in the pathogenesis of atherosclerosis: implications for the oxidized low density lipoprotein hypothesis. Atherosclerosis. 141:1-15.

7. Moncada, S., and Higgs, A. 1993. The L-arginine-nitric oxide pathway. $N$. Engl. J. Med. 329:2002-2012.

8. Jessup, W., Mohr, D., Gieseg, S.P., Dean, R.T., and Stocker, R. 1992. The participation of nitric oxide in cell free- and its restriction of macrophage-mediated oxidation of low-density lipoprotein. Biochem. Biophys. Acta. 1180:73-82.

9. van der Vliet, A., Eiserich, J.P., Kaur, H., Cross, C.E., and Halliwell, B. 1996. Nitrotyrosine as biomarker for reactive nitrogen species. Methods Enzymol. 269:175-184.

10. Lymar, S.V., Jiang, Q., and Hurst, J.K. 1996. Mechanism of carbon dioxide-catalyzed oxidation of tyrosine by peroxynitrite. Biochemistry. 35:7855-7861.

11. Radi, R., Beckman, J.S., Bush, K.M., and Freeman, B.A. 1991. Peroxynitrite-induced membrane lipid peroxidation: the cytotoxic potential of superoxide and nitric oxide. Arch. Biochem. Biophys. 288:481-487.

12. Beckman, J.S., Beckman, T.W., Chen, J., Marshall, P.A., and Freeman, B.A. 1990. Apparent hydroxyl radical production by peroxynitrite: implications for endothelial injury from nitric oxide and superoxide. Proc. Natl. Acad. Sci. USA. 87:1620-1624.

13. Graham, A., et al. 1993. Peroxynitrite modification of low-density lipoprotein leads to recognition by the macrophage scavenger receptor. FEBS Lett. 330:181-185.

14. Beckman, J.S., Chen, J., Ischiropoulos, H., and Crow, J.P. 1994. Oxidative chemistry of peroxynitrite. Methods Enzymol. 233:229-240.

15. Halliwell, B. 1997. What nitrates tyrosine? Is nitrotyrosine specific as a biomarker of peroxynitrite formation in vivo? FEBS Lett. 411:157-160.

16. Beckman, J.S., et al. 1993. Extensive nitration of protein tyrosines in human atherosclerosis detected by immunohistochemistry. Biol. Chem. Hoppe Seyler. 375:81-88.

17. Leeuwenburgh, C., et al. 1997. Reactive nitrogen intermediates promote low density lipoprotein oxidation in human atherosclerotic intima. $J$. Biol. Chem. 272:1433-1436.

18. Christen, S., et al. 1997. Gamma-tocopherol traps mutagenic electrophiles such as $\mathrm{NO}(\mathrm{X})$ and complements alpha-tocopherol: physiological implications. Proc. Natl. Acad. Sci. USA. 94:3217-3222.

19. Hogg, N., Darley-Usmar, V.M. Wilson, M.T., and Moncada, S. 1993. The oxidation of alpha-tocopherol in human low-density lipoprotein by the simultaneous generation of superoxide and nitric oxide. FEBS Lett. 326:199-203.

20. Pfeiffer, S., and Mayer, B. 1998. Lack of tyrosine nitration by peroxynitrite generated at physiological pH. J. Biol. Chem. 273:27280-27285.

21. Klebanoff, S.J., and Clark, R.A. 1978. The neutrophil: function and clinical disorders. Elsevier/North Holland Biomedical Press. Amsterdam, the Netherlands. 447-451.

22. Agner, K. 1972. Structure and function of oxidation-reduction enzymes. A. Akeson and A. Ehrenberg, editors. Pergamon Press. Tarrytown, NY. 329-335.

23. Harrison, J.E., and Schultz, J. 1976. Studies on the chlorinating activity of myeloperoxidase. J. Biol. Chem. 251:1371-1374.

24. Hazen, S.L., Hsu, F.F., Mueller, D.M., Crowley, J.R., and Heinecke, J.W. 1996. Human neutrophils employ chlorine gas as an oxidant during phagocytosis. J. Clin. Invest. 98:1283-1289.

25. van der Vleit, A., Eiserich, J.P., Halliwell, B., and Cross, C.E. 1997. Formation of reactive nitrogen species during peroxidase-catalyzed oxidation of nitrite. A potential additional mechanism of nitric oxide-dependent toxicity. J. Biol. Chem. 272:7617-7625.

26. Eiserich, J.P., et al. 1998. Formation of nitric oxide-derived inflammatory oxidants by myeloperoxidase in neutrophils. Nature. 391:393-397.

27. Krinsky, N.I. 1974. Singlet excited oxygen as a mediator of the antibacterial action of leukocytes. Science. 186:363-365.

28. Daugherty, A., Dunn, J.L., Rateri, D.L., and Heinecke, J.W. 1994. Myeloperoxidase, a catalyst for lipoprotein oxidation, is expressed in human atherosclerotic lesions. J. Clin. Invest. 94:437-444.

29. Hazen, S.L. and Heinecke, J.W. 1997. 3-Chlorotyrosine, a specific marker of myeloperoxidase-catalyzed oxidation, is markedly elevated in low density lipoprotein isolated from human atherosclerotic intima. J. Clin. Invest. 99:2075-2081.

30. Weiss, S.J., Klein, R., Slivka, A., and Wei, M. 1982. Chlorination of taurine by human neutrophils. Evidence for hypochlorous acid generation. J. Clin. Invest. 70:598-607.

31. Hazell, L.J., et al. 1996. Presence of hypochlorite-modified proteins in human atherosclerotic lesions. J. Clin. Invest. 97:1535-1544.

32. Klebanoff, S.J. 1993. Reactive nitrogen intermediates and antimicrobial activity: role of nitrite. Free Radic. Biol. Med. 14:351-360.

33. Eiserich, J.P., Cross, C.E., Jones, A.D., Halliwell, B., and van der Vleit, A. 1996. Formation of nitrating and chlorinating species by reaction of nitrite with hypochlorous acid: a novel mechanism for nitric oxide-mediated protein modification. J. Biol. Chem. 271:19199-19208.

34. Sampson, J.B., Ye, Y., Rosen, H., and Beckman, J.S. 1998. Myeloperoxidase and horseradish peroxidase catalyze tyrosine nitration in proteins from nitrite and hydrogen peroxide. Arch. Biochem. Biophys. 356:207-213.

35. Farrell, A.J., Blake, D.R., Palmer, R.M., and Moncada, S. 1992. Increased concentrations of nitrite in synovial fluid and serum samples suggest increased nitric oxide synthesis in rheumatic diseases. Ann. Rheum. Dis. 51:1219-1222.

36. Torre, D., et al. 1996. Serum concentrations of nitrite in patients with HIV-1 infection. J. Clin. Pathol. 49:574-576.

37. Gaston, B., et al. 1993. Endogenous nitrogen oxides and bronchodilator $S$ nitrosothiols in human airways. Proc. Natl. Acad. Sci. USA. 90:10957-10961.

38. Jiang, Q., and Hurst, J.K. 1997. Relative chlorinating, nitrating and oxidizing capabilities of neutrophil determined with phagocytosable probes. J. Biol. Chem. 272:32767-32772.

39. Markwell, M.A., Haas, S.M., Bieber, L.L., and Tolbert, N.E. 1978. A modification of the Lowry procedure to simplify protein determination in membrane and lipoprotein samples. Anal. Biochem. 87:206-210.

40. Nelson, D.P., and Kiesow, L.A. 1972. Enthalpy of decomposition of hydrogen peroxide by catalase at 25 degrees $\mathrm{C}$ (with molar extinction coefficients of $\mathrm{H}_{2} \mathrm{O}_{2}$ solutions in the UV). Anal. Biochem. 49:474-478.

41. Goldstein, J.L., Ho, Y.K., Basu, S.K., and Brown, M.S. 1979. Binding site on macrophages that mediates uptake and degradation of acetylated low density lipoprotein, producing massive cholesterol deposition. Proc. Natl. Acad. Sci. USA. 76:333-337.

42. Hoppe, G., O’Neil, J., and Hoff, H.F. 1994. Inactivation of lysosomal proteases by oxidized low density lipoprotein is partially responsible for its 
poor degradation by mouse peritoneal macrophages. J. Clin. Invest. 94:1506-1512.

43. Suarna, C., Dean, R.T., May, J., and Stocker, R. 1995. Human atherosclerotic plaque contains both oxidized lipids and relatively large amounts of alpha-tocopherol and ascorbate. Arterioscler. Thromb. Vasc. Biol. 15:1616-1624.

44. Rakita, R.M., Michel, B.R., and Rosen, H. 1990. Differential inactivation of Escherichia coli membrane dehydrogenases by a myeloperoxidase-mediated antimicrobial system. Biochemistry. 29:1075-1080.

45. Wever, R., Plat, H., and Hamers, M.N. 1981. Human eosinophil peroxidase: a novel isolation procedure, spectral properties and chlorinating activity. FEBS Lett. 123:327-331.

46. van Dalen, C.J., Whitehouse, M.W., Winterbourn, C.C., and Kettle, A.J. 1997. Thiocyanate and chloride as competing substrates for myeloperoxidase. Biochem. J. 327:487-492.

47. Hatch, F.T. 1968. Practical methods for plasma lipoprotein analysis. Adv. Lipid Res. 6:1-68.

48. Czerniecki, B.J., et al. 1997. Calcium ionophore-treated peripheral blood monocytes and dendritic cells rapidly display characteristics of activated dendritic cells. J. Immunol. 159:3823-3837.

49. Savenkova, M.L., Mueller, D.M., and Heinecke, J.W. 1994. Tyrosyl radical generated by myeloperoxidase is a physiological catalyst for the initiation of lipid peroxidation in low density lipoprotein. J. Biol. Chem. 269:20394-20400.

50. el-Saadani, M., et al. 1989. A spectrophotometric assay for lipid peroxides in serum lipoproteins using a commercially available reagent. J. Lipid Res. 30:627-630.

51. Ohkawa, H., Ohishi, N., and Yagi, K. 1979. Assay for lipid peroxides in animal tissues by thiobarbituric acid reaction. Anal. Biochem. 95:351-358.

52. Hazen, S.L., Hsu, F.F., Gaut, J.P., Crowley, J.R., and Heinecke, J.W. 1999. Modification of proteins and lipids by myeloperoxidase-derived oxidants. Methods Enzymol. 300:88-105.

53. Crowley, J.R., Yarasheski, K., Leeuwenburgh, C., Turk, J., and Heinecke, J.W. 1998. Isotope dilution mass spectrometric quantification of 3 nitrotyrosine in proteins and tissues is facilitated by reduction to 3 aminotyrosine. Anal. Biochem. 259:127-135.

54. Hazell, L.J., and Stocker, R. 1993. Oxidation of low-density lipoprotein with hypochlorite causes transformation of the lipoprotein into a highuptake form for macrophages. Biochem. J. 290:165-172.

55. Chen, S.H., et al. 1986. The complete cDNA and amino acid sequence of human apolipoprotein B-100. J. Biol. Chem. 261:12918-12921.

56. Ashkenas, J., et al. 1993. Structures and high and low affinity ligand binding properties of murine type I and type II macrophage scavenger receptors. J. Lipid Res. 34:983-1000.

57. Hazell, L.J., van den Berg, J.J., and Stocker, R. 1994. Oxidation of low-density lipoprotein by hypochlorite causes aggregation that is mediated by modification of lysine residues rather than lipid oxidation. Biochem. J. 302:297-304.

58. Panasenko, O.M., Briviba, K., Klotz, L.O., and Sies, H. 1997. Oxidative modification and nitration of human low-density lipoproteins by the reaction of hypochlorous acid with nitrite. Arch. Biochem. Biophys. 343:254-259.

59. Pryor, W.A., and Lightsey, J.W. 1981. Mechanisms of nitrogen dioxide reactions: initiation of lipid peroxidation and the production of nitrous acid. Science, 214:435-437.

60. Thomas, H.V., Mueller, P.K., and Lyman, R.L. 1968. Lipoperoxidation of lung lipids in rats exposed to nitrogen dioxide. Science. 159:532-534.

61. Steinbrecher, U.P., Witztum, J.L., Parthasarathy, S., and Steinberg, D. 1987. Decrease in reactive amino groups during oxidation or endothelial cell modification of LDL. Correlation with changes in receptor-mediated catabolism. Arteriosclerosis. 7:135-143.

62. Haberland, M.E., Olch, C.L., and Folgelman, A.M. 1984. Role of lysines in mediating interaction of modified low density lipoproteins with the scavenger receptor of human monocyte macrophages. J. Biol. Chem. 259:11305-11311.

63. Khoo, J.C., Miller, E., McLoughlin, P., and Steinberg, D. 1988. Enhanced macrophage uptake of low density lipoprotein after self-aggregation. Arteriosclerosis. 8:348-358.

64. Suits, A.G., Chait, A., Aviram, M., and Heinecke, J.W. 1989. Phagocytosis of aggregated lipoprotein by macrophages: low density lipoprotein receptor-dependent foam-cell formation. Proc. Natl. Acad. Sci. USA. 86:2713-2717.

65. Schissel, S.L., et al 1996. Rabbit aorta and human atherosclerotic lesions hydrolyze sphingomyelin of retained low-density lipoprotein: proposed role for arterial-wall sphingomyelinase in subendothelial retention and aggregation of atherogenic lipoproteins. J. Clin. Invest. 98:1455-1464.

66. Hoff, H.F., Whitaker, T.E., and O'Neil, J. 1992. Oxidation of low density lipoprotein leads to particle aggregation and altered macrophage recognition. J. Biol. Chem. 267:602-609.

67. Kikugawa, K., Beppu, M., and Okamoto, Y. 1995. Uptake by macrophages of low-density lipoprotein damaged by nitrogen dioxide in air. Lipids. 30:313-320.

68. Chang, G.J., et al. 1994. Oxidation of LDL to a biologically active form by derivatives of nitric oxide and nitrite in the absence of superoxide. Dependence on $\mathrm{pH}$ and oxygen. Arterioscler. Thromb. 14:1808-1814.

69. Cy, Y., et al. 1999. Selective modification of apo B-100 in the oxidation of low density lipoproteins by myeloperoxidase in vitro. J. Lipid. Res. 40:686-698.

70. Leeuwenburgh, C., et al. 1997. Mass spectrometric quantification of markers for protein oxidation by tyrosyl radical, copper, and hydroxyl radical in low density lipoprotein isolated from human atherosclerotic plaques. J. Biol. Chem. 272:3520-3526.

71. Folcik, V.A., Aristy-Nivar, R.A., Krajewski, L.P., and Cathcart, M.K. 1995. Lipoxygenase contributes to the oxidation of lipids in human atherosclerotic plaques. J. Clin. Invest. 96:504-510.

72. Kettle, A.J. 1996. Neutrophils convert tyrosyl residues in albumin to chlorotyrosine. FEBS Lett. 379:103-106.

73.Hazen, S.L., Crowley, J.R., Mueller, D.M., and Heinecke, J.W. 1997. Mass spectrometric quantification of 3-chlorotyrosine in human tissues with attomole sensitivity: a sensitive and specific marker for myeloperoxidase-catalyzed chlorination at sites of inflammation. Free Radic. Biol. Med. 23:909-916.

74. Weiss, S.J., Lampert, M.B., and Test, S.T. 1983. Long-lived oxidants generated by human neutrophils: characterization and bioactivity. Science. 222:625-628.

75. Nathan, C.F. 1987. Neutrophil activation on biological surfaces. Massive secretion of hydrogen peroxide in response to products of macrophages and lymphocytes. J. Clin. Invest. 80:1550-1560. 